\title{
DA FRAUDE À CONSTITUIÇÃO NO SISTEMA JURÍDICO NACIONAL
}

\author{
FRAUD TO THE CONSTITUTION IN THE NATIONAL LEGAL SYSTEM
}

Marcos Bernardes de Mello*

RESUMO: É comum, ao menos no Estado brasileiro, a edição de leis e outros atos normativos e administrativos que violam, flagrantemente, preceitos da Constituição. Menos comuns, no entanto, são leis e atos normativos que, aparentando compatibilidade com a Constituição, em essência, violam seus preceitos: é o problema da inconstitucionalidade por fraude (=infração indireta) à Constituição. Em relação ao primeiro aspecto da inconstitucionalidade, o Direito Constitucional, nacional e estrangeiro, o tem estudado com bastante proficiência e a jurisprudência do STF se aprimora a cada momento, sendo expressiva a bibliografia a respeito. Quanto ao segundo aspecto, porém, nunca lhe foi dedicada a devida atenção, de modo que é praticamente inédito na literatura jurídica nacional. Assim também na doutrina estrangeira (apenas na Itália essa questão teve alguma repercussão por ocasião da reforma agrária do planalto de Sila). Este estudo quer contribuir para a Teoria Geral do Direito, em especial a Teoria da Constituição, revisando conceitos sobre o problema da violação das normas jurídicas e suas implicações com referência ao conflito de leis e atos normativos com regras e princípios constitucionais, com a finalidade de demonstrar que a inconstitucionalidade por fraude à Constituição em nada difere, em essência, da inconstitucionalidade direta, de modo que devem ter o mesmo tratamento.

PALAVRAS-CHAVE: Fraude à Constituição. Inconstitucionalidade. Conflito de leis.

ABSTRACT: It is common, at least in Brazil, to edit laws and other normative and administrative acts that flagrantly break the rules of the Constitution. Less common, however, are the laws and normative acts that, apparently compatible with the Constitution, in fact, violate its rules: it is the problem of unconstitutionality by fraud (=indirect violation) to the Constitution. With regard to the first aspect of unconstitutionality, Constitutional law -national and foreign- was studied with sufficient proficiency and the precedents of the Brazilian Supreme Court are expressive as well as the bibliography about it. With regard to the second aspect the proper attention was never dedicated to it and it is practically unknown in national legal literature. Also in foreign doctrine (only in Italy this question had some repercussion during the agrarian reform of plateau of Sila). This study wants to contribute to the General Theory of Law, especially to the Theory of the Constitution reviewing concepts about the problem of breaking the law and its implications such as the conflict of laws and normative acts with constitutionals rules and principles. It intends to show that unconstitutionality by fraud to the Constitution do not differ, in essence, to direct unconstitutionality, in a way that they must be treated equally.

KEYWORDS: Fraud to the Constitution. Unconstitutionality. Conflict of rules.

* Professor Emérito da UFAL. PhD em Direito do Estado. Professor de Teoria Geral do Direito no Curso de Mestrado da Faculdade de Direito de Alagoas (FDA/UFAL). Professor de Teoria Geral do Direito Civil na FDA/ UFAL (graduação). E-mail: mbmello@uol.com.br 


\section{INTRODUÇÃO}

\section{I.1 JUSTIFICAÇÃO DO TEMA}

O problema da inconstitucionalidade das leis e atos normativos envolve múltiplos aspectos e, por essa razão, ainda não foi equacionado por completo e de modo definitivo. É matéria em plena ebulição. Há sempre aspectos que escapam à análise dos estudiosos, ou por uma atitude simplesmente metodológica, procedendo-se a um corte epistemológico delimitativo do objeto do estudo, ou por não lhes despertarem interesse científico ou mesmo por desconhecimento de sua existência.

Apesar de o tema da inconstitucionalidade haver sido objeto de notáveis estudos, há uma de suas facetas que não mereceu, ainda, análise mais aprofundada: a questão da inconstitucionalidade da lei que de um modo indireto, com aparência de compatibilidade com norma ou princípio constitucional, viola-o, fraudando-o.

A problemática da violação indireta das normas jurídicas, mais especificamente das leis, já estava presente na preocupação dos jurisconsultos romanos ${ }^{1}$, que se referiam a esse expediente ilícito, com a denominação de fraude à lei, como hoje ainda o faz, usualmente, porém, com impropriedade ${ }^{2}$, a maciça maioria dos doutrinadores que dela tratam, com maior ou menor profundidade. Na literatura jurídica estrangeira, a fraude à lei tem sido estudada com bastante interesse, mas nem sempre com a devida acuidade, em especial nos planos do Direito Internacional e do Direito Civil, áreas em que esses expedientes de infringir as leis com aparência de legalidade são mais intensamente utilizados. Em doutrina nacional, só existem raras obras que dela tratam de modo mais aprofundado ${ }^{3}$.

No plano do Direito Constitucional, raros são os estudos que lhe foram dedicados. No que se refere à inconstitucionalidade das leis conhecemos apenas raríssimas referência feitas por Pontes de Miranda em seus Comentários à Constituição Federal de 1967, e Ivo Dantas (2001), que se refere à fraude à Constituição na atuação do constituinte derivado nacional que vem promulgando emendas constitucionais cujos conteúdos são de verdadeiras reformas constitucionais.

Nesse assunto, em particular, a jurisprudência nacional também é muito escassa. Decisões específicas, há duas: uma do STJ proferida no RMS 1.796-5-SP, rel. Min.

1 Paulo, na L. 29, D.,de legibus senatusque consultis et longa consuetudine, 1.3, Ulpiano, L.30, Teodosio, L.5, C., de legibus et constitutionibus principium et edictis, 1,14 .

2 Usaremos a expressão fraude à lei ao longo deste estudo em razão de ser de comum emprego na literatura jurídica, embora reconhecendo a sua impropriedade, que será discutida oportunamente, no texto.

3 Dentre os poucos estudos mais alentados, vale destacar Pontes de Miranda, Tratado de direito privado, t.I, p.43, Homero Prates, Atos simulados e atos em fraude da lei, Regis Fichtner Pereira, A fraude à lei, e Marcos Bernardes de Mello, Teoria do fato jurídico: plano da validade, § 32. A indicação bibliográfica completa se encontra ao final deste trabalho. 
Humberto Gomes de Barros, DJU de 4 out. 1993, p. 20501, e outra do Tribunal Regional Federal da $4^{\mathrm{a}}$. Região na AMS 976-AL, Salgema Mineração Ltda. e outra X Fazenda Nacional, Rel. Juiz Hugo Machado. Mas, nesta última não se faz referência a que haveria uma fraude à Constituição ou mesmo uma violação indireta de suas normas.

$\mathrm{O}$ tema da lei em fraus constitutioni, portanto, é praticamente inédito ao menos na literatura jurídica e jurisprudência nacionais.

Em doutrina estrangeira, ao que parece, essa questão da lei em fraude à Constituição, foi discutida pela primeira, e talvez, única vez na Itália em face da Lei de 12 de maio de 1950, no 230, que, visando à realização de reforma agrária e fundiária na região de Sila, denominada, por isso, Lei Silana, procurou impedir a discussão em juízo ordinário das desapropriações necessárias à sua efetivação.

Na Espanha, em obra intitulada Fraude contra Derecho, José Lois Estévez acusa os partidos políticos espanhóis de se mancomunarem para fraudar princípios constitucionais.

Além dessa carência doutrinária, tratar deste tema, mesmo que com certa superficialidade, em razão da limitação de espaço de que aqui dispomos, se justifica em razão de sua atualidade que ressalta do modo com que, na legislação brasileira, tem sido usado o expediente de legislar com aparente normalidade, quando, em verdade, estão sendo infringidas normas constitucionais. Notadamente no campo do Direito Tributário, impostos são denominados contribuições sociais para lesar a participação dos Estados e Municípios em sua receita; medidas provisórias são reeditadas violando a regra constitucional da irrepetibilidade, na mesma sessão legislativa, de projeto de lei rejeitado; garantias do funcionalismo são desrespeitadas, contornando-se imposições constitucionais; o processo legislativo constitucional é violado, com medidas regimentais; dão-se denominações diversas a espécies legislativas, para burlar limitações constitucionais, dentre outras práticas fraudulentas. Essas questões serão analisadas no devido tempo, no desenvolver do tema, em relação ao qual parecem indiscutíveis sua relevância e seu ineditismo na doutrina e jurisprudência nacionais.

\section{I.2 DELIMITAÇÃO TEMÁTICA}

Este estudo constitui um esboceto de trabalho de maior fôlego com que se pretende dar uma contribuição à teoria da inconstitucionalidade das leis e atos normativos, enfatizando esse aspecto da inconstitucionalidade por infração indireta às normas constitucionais.

Para alcançar esse desideratum, não é possível excluir-se o exame da natureza da inconstitucionalidade, seus fundamentos e suas consequências com o objetivo de demonstrar que, em essência, sua decretação constitui uma sanção imposta ao ato legislativo que infringe a Constituição e não um mero critério para resolver conflitos (antinomias) entre normas de diferentes graus hierárquicos. Por necessidade metodológica, ter-se-á de desenvolver um estudo da problemática da infração das normas jurídicas em 
geral, desde suas razões fundantes às suas implicações, bem como sobre a própria inconstitucionalidade, inclusive, em sede de direito positivo nacional, quanto às suas características, seu controle e a eficácia de sua decretação, enfim, tudo o que, relacionado ao tema, seja imprescindível para alicerçar a conclusão de que há inconstitucionalidade quando a lei ou ato normativo viola a Constituição por meio indireto, aparentemente lícito, o que vale dizer, frauda a Constituição.

\section{PREMISSAS TEÓRICAS RELATIVAS À INFRAÇÃo DAS NORMAS JURÍDICAS}

\section{II.1 DIREITO, OBRIGATORIEDADE E COERCIBILIDADE}

\section{II.1.1 Homem e adaptação social}

O homo socialis não constitui um produto da natureza, mas o resultado de constante adaptação imposta pela sociedade. Desde o nascimento, passando pelas fases de seu desenvolvimento natural e a ampliação dos círculos de contato social, o homem recebe a instilação das exigências da comunidade, que se utiliza de processos de adaptação social, como a Moral, a Religião, a Política, a Ciência, a Economia, a Arte, a Etiqueta, a Moda e o Direito, cujas normas de conduta têm por fim procurar manter o comportamento humano dentro de padrões que permitam uma convivência a mais harmônica possível ${ }^{4}$.

Essas normas comportamentais, exceto as do Direito, não são providas de coercibilidade exterior. Levando-se em conta o livre arbítrio de que é dotado o ser humano, como parte inamovível de sua essência, o seu comportamento nem sempre leva em consideração as normas de adaptação social, agindo de modo com elas incompatível. Proceder segundo as normas ou infringi-las é questão que se põe no âmbito estritamente da conveniência individual, sendo impossível remover-se essa opção do espírito de cada qual. A liberdade de ação que tem o homem não permite esperar que normas que não se formaram em sua consciência ou que a ela não se hajam integrado, mas que são postas e impostas pelo grupo social, possam anular o seu poder de escolha da conduta a seguir. Assim, apesar de todo o aparato social, não há como eliminar-se a sempre atual e permanente possibilidade de que o homem descumpra as normas da adaptação social.

4 Pontes de Miranda, Tratado de direito privado, t. I, Prefácio et passim; Marcos Bernardes de Mello, Teoria do fato jurídico: plano da existência, Cap.I; Paulo Nader, Filosofia do direito, n.16; Introdução ao estudo do direito, $\mathrm{n}^{\circ} 8$ et passim. É preciso levar em conta que praticamente todos os filósofos do direito se referem a essas normas existentes na sociedade, embora não utilizem a mesma expressão processos de adaptação social, preferindo outras como normas convencionais (Stammler, Filosofia del derecho, p.102, Ricaséns Siches, regras do trato social (Tratado general de filosofia del derecho, p.199 et passim,), Groppali, normas de conduta (Introdução ao estudo do direito, 32 et passim, Angel Latorre, normas de correção social, normas de natureza ética (Introdução ao direito, p.17), dentre tantas outras. 


\section{II.1.2 A impositividade incondicional do direito e a conduta humana livre}

Por esse motivo, como tentativa mais enérgica para conter as irracionalidades humanas no plano das interferências intersubjetivas, a sociedade atribui caráter obrigatório às normas de um desses processos de adaptação social, o Direito ${ }^{5}$, acobertando-as pela coercibilidade exterior garantida pela comunidade jurídica ${ }^{6}$. Essa obrigatoriedade coercitiva do Direito constitui a differentia specifica que o distingue dos demais processos de adaptação social e atende à necessidade de negar-se que o livre arbítrio do homem possa ser a regra preponderante e regente das relações interhumanas (PONTES DE MIRANDA, 1972, I, p. 9; MELLO, 2008a, $\S 1^{\circ}$ ). O reconhecimento a cada qual da faculdade de conduzir-se segundo seus desejos e consciência implicaria erigir o primado da força como preceito máximo de convivência, o que certamente tornaria intolerável a vida em sociedade. A existência do próprio Estado perderia sentido uma vez que constituem sua essência a criação e preservação da ordem, como anota Bockelmann ${ }^{7}$.

Por essas razões, é evidente a exigência lógica de que o Direito seja vinculativo (=obrigatório) da conduta das pessoas, incondicionalmente; a obrigatoriedade de suas normas, assim, independe da adesão a seus comandos daqueles que sejam seus destinatários. A incondicionalidade do Direito, entretanto, jamais pode suprimir, nem mesmo reduzir, o livre arbítrio do homem na escolha de sua conduta, mas, por causa dela, a norma jurídica, qualquer que seja, é incólume à conduta humana contrária a suas disposições, de modo que a sua violação não afeta, em nada, a sua valência ${ }^{8}$ e vigência. Enquanto outra norma não a revogar a norma permanece vigente, mesmo se não cumprida pelas pessoas. No entanto, a desobediência à norma, eventual ou contumaz, constitui uma teratologia no meio social que, evidentemente, afeta a respeitabilidade de todo o ordenamento jurídico. Por isso, o Direito de todos os povos, desde todas as épocas, tem na coercibilidade

5 A obrigatoriedade do Direito é dado que se põe a priori, expressão essa aqui empregada no sentido adotado por Locke, seguido com pequenas diferenças, por Hume, Liebnitz, Wolff e Kant, entre outros, de conhecimento alcançável mediante o exercício da pura razão, que independe da prévia experiência, portanto, que não precisa ser provado.

${ }^{6}$ Com a expressão comunidade jurídica designamos o grupo social que detém o poder político reconhecido pelo direito das gentes de ditar aplicar.

7 Bockelmann, The principles of the rule of law, p. 97. Vide ainda, nosso Direito, uma concepção de sua validade, p.7 e s., e Bodenheimer, Ciência do direito, filosofia e metodologia jurídicas, 190.

${ }^{8}$ A doutrina, inspirada em Kelsen, emprega, geralmente, a palavra validade no sentido em que aqui usamos o vocábulo valência, o que fazemos para evitar confusão terminológica, porque, numa atitude que nos parece cientificamente correta, validade é termo que deve expressar, tão somente, o fato de uma norma ser perfeita do ponto de vista dogmático (=não conter qualquer vício que a torne nula: inconstitucionalidade, por exemplo). Valência, diferentemente, tem cunho axiológico e serve para definir o poder vinculativo de uma norma jurídica no plano lógico da normatividade. (Vide, sobre isto, nosso, Teoria do fato jurídico:plano da eficácia, nota n.4, a partir da $4 .^{\text {a }}$ edição. (MELLO, 2008c) 
(=possibilidade de coerção externa, por meio de sanções) o instrumento para manter a integridade do sistema jurídico e a respeitabilidade de suas normas.

A coercibilidade, porém, é característica inerente ao Direito como processo de adaptação social e ao sistema jurídico como um todo, não às suas normas em particular, individualmente. Ao contrário do que afirmam os normativistas, em especial os de inspiração kelseniana, a norma jurídica não precisa, necessariamente, conter em sua formulação proposicional uma sanção explícita. Sua força coercitiva existe assim mesmo, porque é assegurada pela coercibilidade do sistema jurídico ${ }^{9}$. Portanto, a afirmativa de vários doutrinadores de que norma sem sanção não seria norma jurídica em sentido próprio, mas leges imperfectoe (Jellineck), normas não autônomas (Kelsen), normas auxiliares etc., não nos parece correta. Para demonstrar a procedência dessas afirmativas, é essencial uma breve descrição de como se desenvolve o fenômeno jurídico, segundo a concepção de Pontes de Miranda, a única que o explica, lógica, cientifica e sistematicamente, em sua totalidade.

\section{II.1.3 Incidência e obrigatoriedade da norma jurídica}

As normas jurídicas são proposições que, abstratamente, preveem fatos ${ }^{10}$ aos quais são imputadas consequências em relação ao comportamento das pessoas que sejam por eles afetados ${ }^{11}$. Os fatos descritos na norma são denominados suportes fáticos e às consequências jurídicas (= efeitos jurídicos) prescritas dá-se a denominação de preceito $^{12}$. Sempre que o suporte fático hipoteticamente descrito na norma se concretiza no mundo (=suporte fático concreto), a norma jurídica que o prevê sobre ele incide e o transforma em fato jurídico, por força do qual os efeitos jurídicos a ele imputados no preceito serão

\footnotetext{
9 Vejamos um exemplo bastante prosaico para demonstrar a procedência dessa afirmativa. A Constituição de 1988 (art.5º I)e o Código Civil (art.1.511) declaram que, no casamento, entre marido e esposa há igualdade de direitos e deveres. Apenas declaram, sem prescreverem qualquer penalidade para o caso de serem infringidas pela recusa dessa igualdade por um dos cônjuges. Certo marido nega à sua esposa essa igualdade na relação matrimonial. A mulher vai a juízo e obtém uma sentença em que o juiz lhe assegura a igualdade, dando cumprimento das normas jurídicas. Apesar disto, o marido continua a negar a igualdade à esposa, em desrespeito à decisão judicial. Denunciado o fato, o juiz instaura processo criminal e pune o marido pelo crime de desobediência a decisão judicial previsto no art. 359 do Código Penal. Por uma sanção indireta pune-se a conduta de desrespeito à norma da igualdade e se mantém a respeitabilidade da norma e do ordenamento.

${ }^{10} \mathrm{Na}$ concepção ponteana, fato é tudo o que ocorre no mundo, seja evento (=fatos da natureza, mesmo quando relacionado ao homem) e conduta (=fatos criados pelo homem, atos); o mundo mesmo é a soma de todos os fatos que ocorreram, estão ocorrendo e o palco onde irão ocorrer.

${ }^{11}$ Sobre a fenomenologia da juridicidade, veja-se Marcos Bernardes de Mello, Teoria do fato jurídico: plano da existência (MELLO, 2008a). Mais extensamente, Pontes de Miranda, Tratado de direito privado, t. I, passim (PONTES DE MIRANDA, 1972).

${ }^{12}$ Essa terminologia foi criada por Pontes de Miranda. Doutrinadores, no entanto, empregam outras expressões, como hipótese de incidência, fato gerador, antecedente, para denominar o suporte fático e disposição, consequente, para nomear o preceito, dentre outras mais.
} 
gerados. A incidência, portanto, constitui o efeito que tem a norma jurídica de transformar em fato jurídico o seu suporte fático.

Segundo essa visão, o fenômeno jurídico pode ser assim descrito, esquematicamente:

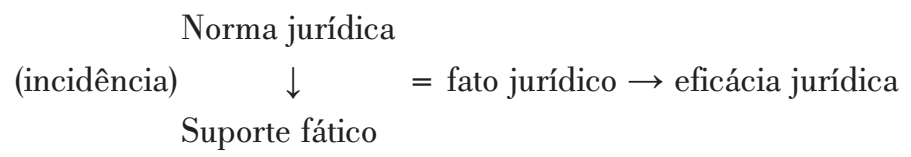

A incidência, segundo a concepção ponteana, ocorre infalivelmente, fatalmente. Independe da adesão das pessoas. Dado o fato, dá-se a incidência, de modo que não está condicionada à vontade das pessoas, salvo quando a própria norma a tem como elemento nuclear de seu suporte fático (vide adiante sobre norma não-cogente). A incidência, em razão de sua incondicionalidade em transformar o suporte fático em fato jurídico, tem a consequência de tornar a norma de obrigatória aplicação pelo juiz. Antes de incidir, a norma jurídica constitui tão somente uma proposição linguística: descreve uma hipótese fática que poderá vir a materializar-se no mundo e prescreve uma conduta humana desejável em face daquela hipótese. Evidentemente, desde que vigente, tem efeitos vinculativos das pessoas, em razão do que as pessoas devem comportar-se conforme prescrito na norma. Apesar disto, ainda não é de aplicação obrigatória. Somente depois que se dá a incidência e se cria o fato jurídico é que a norma se torna obrigatória, porque não podem deixar de ser atendidos os seus efeitos, sob pena de ser infringida. Por isso se diz que a obrigatoriedade da norma decorre de sua incidência.

\section{II.2 DAS NORMAS JURÍDICAS EM FACE DA INCONDICIONALIDADE DA INCIDÊNCIA}

\section{II.2.1 Impositividade lógica das normas jurídica (= cogência)}

As normas jurídicas, em geral, são concebidas de modo que a sua incidência não pode ser afastada pela vontade das pessoas; impõem-se, logicamente, a todos. Em certas áreas do direito, no entanto, é reconhecido às pessoas, ao exteriorizarem sua vontade para compor suportes fáticos de atos jurídicos lato sensu, o poder de escolha da categoria jurídica e de autorregularem o conteúdo das relações jurídicas segundo seus interesses, diferentemente do que prescrevam disposições normativas postas (=poder de autorregramento da vontade, também dito poder de autonomia da vontade, ou, com menor propriedade, de autonomia privada ${ }^{13}$ ). A concessão desse poder de autorregramento

${ }^{13}$ A impropriedade da expressão autonomia privada reside na circunstância de que esse poder não se limita aos indivíduos (como sugere o vocábulo privada), mas também às pessoas jurídicas de direito público. 
da vontade leva sempre em conta a possibilidade de as pessoas serem omissas quando manifestam sua vontade para compor suportes fáticos de atos jurídicos ou de a declararem de modo obscuro ou ambíguo, o que poderá, muitas vezes, dificultar ou mesmo tornar impossível saber-se qual a vontade real que instrumenta o negócio jurídico. Em face disto, os sistemas jurídicos adotam normas que se destinam, tão somente, a suprir essas omissões ou a aclarar essas obscuridades ou ambiguidades, o que implica o reconhecimento da liberdade às pessoas de exteriorizar a vontade em sentido outro que não o das normas, permitindo seja afastada a sua incidência.

Em face disso, é evidente que a impositividade lógica (=inafastabilidade da incidência, cogência) não existe em todas as normas jurídicas, donde serem elas classificáveis, sob esse aspecto, em $(a)$ cogentes e (b) não cogentes.

(a) As normas jurídicas cogentes, também denominadas imperativas, são aquelas cuja incidência é incondicional; compostos seus suportes fáticos, incidem infalivelmente, independentemente do querer das pessoas. Não há margem ao poder de autorregramento da vontade, de modo que jamais podem ter sua incidência afastada pela vontade dos figurantes dos negócios jurídicos. São de duas espécies: (i) proibitivas, as que ou proíbem uma específica conduta (e.g.arts. 426, $1055, \S 2^{\circ}$ ) ou vedam seja alcançado certo resultado (Código Civil, art. 412, 496) e (ii) impositivas, as que impõem se deva observar uma determinada conduta (e.g. Código Civil, arts. 422, 967, 979, 1.183) ou que se produza certo resultado (e.g.Código Civil, art. 1.146, $1.192,2^{\text {a }}$ parte $v . g$.)

(b') As normas não-cogentes, ao contrário, deixam margem a que a vontade seja manifestada de modo diferente daquele nelas previstos, e são também de duas espécies: ( $i$ ) dispositivas, as formuladas para preencher vazios (=omissões) deixados pela vontade quando poderia ser manifestada em outro sentido (e.g. Código Civil, arts.547, 578,1.050) e (ii) interpretativas as que se destinam a dar sentido à vontade quando exteriorizada de modo obscuro, ambíguo ou duvidoso (Código Civil, arts. 1092, 1.904, v.g).

Em ocorrendo omissão, obscuridade ou ambiguidade quando da manifestação da vontade, concretiza-se o suporte fático das normas não cogentes, de modo que elas incidem, apesar da facultatividade que as caracteriza, e, em decorrência, se torna obrigatória sua aplicação como qualquer outra norma. A facultatividade que nelas existe está relacionada ao poder de autorregramento da vontade e reside apenas na possibilidade atribuída às pessoas de adotá-las ou não.

O conhecimento dessas espécies é essencial ao estudo da infração das normas jurídicas.

\section{II.3 DA INFRAÇÃO DAS NORMAS JURÍDICAS.}

\section{II.3.1 Modos de violação das normas jurídicas}

De duas maneiras podem as normas jurídicas ser violadas:

(a) diretamente, quando há, simplesmente, conduta contrária a suas determinações; 
(b) indiretamente, sempre que, mesmo por meios considerados lícitos, ou pelo emprego de meios em geral ardilosos, aparentemente lícitos, se obtém resultado proibido ou se evita fim por ela imposto. $\mathrm{O}$ que importa para que se tenha a infração indireta é o fim alcançado com o ato jurídico, e não o meio utilizado para alcançá-lo. A essa espécie se costuma denominar fraude à lei, embora com certa impropriedade, consoante se mostrará oportunamente.

\section{II.3.2 Da violação direta das normas jurídicas}

Todas as normas jurídicas cogentes, mas somente elas, são passíveis de serem infringidas diretamente. As normas não cogentes, diferentemente, não podem ser violadas, uma vez que é de sua essência permitir que as pessoas escolham atuar de modo diverso do nelas previsto. Em passado não muito remoto, afirmava-se, em doutrina fundada na jurisprudência reinante, que somente quando houvesse literal disposição de lei seria admissível falar em infração de norma jurídica. Se não houvesse lei explícita, portanto, não haveria violação da norma. Essa concepção, resultante de um exagerado apego ao legalismo inspirado na Escola da Exegese, é que serviu de norte ao Legislador Processual pátrio, desde 1939, quando, ao enumerar as hipóteses permissivas de rescisão de sentença, utilizou-se daquela expressão (CPC, atual art.485, V).

Tal ponto de vista, porém, restou superado quando o STF passou a entender que a expressão legislativa violação de literal disposição de lei deveria ser lida como violação de direito expresso. Em face desse entendimento, a disposição do Código Civil (art. 166,VI) que impõe a sanção da nulidade ao negócio jurídico que tenha a finalidade de fraudar lei imperativa deve ser interpretada da mesma maneira: nulo é o negócio jurídico que frauda direito cogente expresso. Assim, não apenas normas explícitas, mas também normas implícitas nos princípios que norteiam o sistema jurídico podem ser objeto de infração.

Com efeito, constitui hoje opinião incontroversa a de que o Direito de uma comunidade tem abrangência maior do que o ordenamento objetivamente posto em leis e atos normativos, explicitamente. Os sistemas jurídicos são integrados por mais normas jurídicas do que as explícitas (=previstas em atos normativos em geral): são as normas implícitas nos princípios e nos costumes, por meio das quais se alcança a sua plenitude lógica. Em verdade, o Direito de uma determinada comunidade jurídica para ser legítimo, deve expressar os valores que a inspiram em sua missão de obter a adaptação social, com vistas à distribuição dos bens da vida. $\mathrm{O}$ dado axiológico que existe no Direito constitui o elemento determinante da orientação imprimida ao sistema jurídico e se cristaliza nos princípios fundamentais regentes de suas instituições jurídicas. Por isso, as diversas áreas que integram o universo jurídico de uma comunidade têm sua estrutura conceptual alicerçada em princípios gerais que consubstanciam a sua valoração em relação aos fatos da vida. Nessa categoria não estão apenas os princípios inseridos nas Constituições, mas também os tradicionalmente denominados princípios gerais do direito. 
Os princípios ou são minudenciados em normas explícitas, ou apenas enunciados com a generalidade que lhes é peculiar, ou, ainda, implícitos (= não declarados em normas específicas), permanecendo dentro do sistema jurídico como instrumentos normativos disponíveis, especialmente, para o preenchimento das lacunas do ordenamento positivado. Os princípios, quando enunciados em documentos legislativos, só por si regem as situações sociais que a eles se relacionam. O mesmo ocorre com os princípios implícitos. Quando a legislação é insuficiente para a solução de casos concretos, tornase imperiosa a revelação de normas a partir do conteúdo dos princípios que, em última análise, dão sentido ao sistema jurídico. Os princípios, por isso, são cogentes, como quaisquer outras normas, quanto às matérias de que tratam.

Até bem recentemente, o positivismo jurídico levado a níveis paroxísticos, ligava o Direito unicamente às normas expressadas em leis e recusava caráter normativo aos princípios, mesmo quando enunciados em documentos legislativos. Princípio era visto apenas como mera enunciação de diretriz, de valores, recomendação, programa, recusando-lhe caráter normativo. Essa atitude se refletia, objetivamente, no entendimento, hoje já superado, do STF de não admitir o controle da constitucionalidade de leis, atos normativos e mesmo de atos administrativos por violação a princípio constitucional. Hodiernamente, no entanto, algumas concepções doutrinárias, sob fundamentações diversas, fixam-se no sentido de afirmar que os princípios têm a mesma força vinculante de qualquer outra norma jurídica positivada.

Sempre foi esse nosso entendimento. Nunca encontramos argumento que parecesse suficientemente razoável para negar caráter normativo aos princípios. Ao contrário, consoante está claro em nosso Teoria do fato jurídico: plano da existência, nota n.17-A, não há dúvida de que os princípios preenchem os pressupostos necessários para caracterizá-los como norma jurídica, seja qual for a concepção que se tenha de norma jurídica. De efeito, segundo a visão clássica de norma jurídica aprimorada pelo gênio de Pontes de Miranda, para ser considerada jurídica, uma norma há de atender, além da circunstância de ser ditada por quem detenha poder normativo na comunidade jurídica, a duas exigências essenciais: (i) uma formal, referente à completude de sua estrutura proposicional, que deve conter, essencialmente, a descrição de um suporte fático e a prescrição de um preceito; (ii) outra de natureza material, concernente ao poder de incidência, em decorrência da qual as condutas previstas ficam vinculadas a seus comandos (=obrigatoriedade $)^{14}$.

(i) Analisados conforme essa óptica, chega-se à óbvia constatação de que, do ponto de vista formal, os princípios ostentam uma estrutura lógica completa; mesmo

${ }^{14}$ Vide sobre a isto, Notas sobre o caráter normativo dos princípios e das normas programáticas, in Revista do mestrado em direito da Universidade Federal de Alagoas, ano 2, n 3-2 ${ }^{\circ}$ Semestre 2008, p.79 a 114, Maceió, EDUFAL, 2008. 
quando há caso de acentuada indeterminação da linguagem normativa, contêm a descrição de um suporte fático e a prescrição de um preceito. Exemplifiquemos: $(a)$ o princípio constitucional da isonomia $\left(\mathrm{CF} / 88\right.$, art. $5^{\circ}$, caput $)$, e.g., tem por pressupostos fáticos (=suporte fático) a existência de pessoas em situações fáticas ou jurídicas iguais, e por preceito o comando dirigido ao legislador, ao poder público e, em geral, a qualquer pessoa de que não lhes é permitido dar tratamento (legislativo ou administrativo) diverso a situações de igualdade ou, inversamente, de tratar igualitariamente sujeitos em posições que sejam desiguais; (b) o princípio da universalidade da capacidade jurídica (Código Civil, art. $1^{\circ}$ ), tem por suporte fático o fato da existência de um ser humano, independentemente de seu grau de sanidade física ou mental, e por preceito a atribuição a todos da capacidade de ser sujeito em uma situação jurídica (= possibilidade de ser titular de direitos e deveres); (c) o princípio da presunção de inocência do acusado criminalmente tem por suporte fático a existência de alguém acusado da prática de um crime e por preceito a impossibilidade de ser considerado criminoso, enquanto não transitada em julgado a sua condenação.

Para atender a essa exigência, não importa o grau de determinação linguística da proposição que enuncia o princípio; basta que, pela interpretação de seu conteúdo, se possa identificá-lo e relacioná-lo a dados da realidade (o grande problema para compreender e aceitar a afirmativa de que princípio é uma norma jurídica reside no fato de que a grande generalidade de sua formulação induz a que nem sempre sejam vistos [=identificados] os elementos de sua estrutura normativa. Se, entretanto, considerarmos que as normas jurídicas podem ser expressadas com maior ou menor grau de determinação, tanto em relação ao suporte fático como ao preceito, e que essa circunstância não afeta sua normatividade, chegaremos à evidência de que os princípios são apenas casos de indeterminação na expressão dos dados de sua estrutura lógica. A determinação ou indeterminação dos enunciados normativos constitui questão absolutamente irrelevante quando se trata de caracterizar a normatividade).

(ii) Em relação à segunda exigência, também não há como negar que os princípios sejam dotados do poder de incidir e que, por isso, sejam vinculantes das condutas a que se referem. A aplicabilidade das normas jurídicas depende de sua incidência, de modo que somente podem ser aplicadas quando incidem. Pela incidência é que os fatos da vida são regrados e as condutas correspondentes ficam vinculadas à norma jurídica. Ora, quando o Judiciário, por exemplo, decreta a inconstitucionalidade de certa lei por conflitar com determinado princípio constitucional, está, em última análise, a reconhecer a incidência de dois princípios: (a) do princípio implícito da supremacia da Constituição, segundo o qual todos estão sujeitos aos seus ditames, e $(b)$ do princípio explícito com o qual o ato legislativo colide diretamente. Se os princípios não fossem vinculativos, se o poder político pudesse agir livremente, contrariando-os, sem que houvesse qualquer instrumento de reação do sistema jurídico destinado a repelir a violação e, portanto, 
apto a manter a sua integridade, como um todo, e a vigência de suas normas, em particular, então seria possível dizer que os princípios não incidem e, portanto, não têm caráter normativo.

Mas, não é somente com fundamento na concepção ponteana de norma jurídica que se demonstra o caráter normativo dos princípios jurídicos. Também se apreciada a questão conforme a doutrina kelseniana, que vê na sanção punitiva o dado essencial para caracterizar uma norma jurídica, concluir-se-á que os princípios, sem dúvida, atendem a esse requisito. Demonstra-se.

A decretação de inconstitucionalidade de uma lei, ato normativo ou ato jurídico do poder público implica uma sanção imposta por violação de norma constitucional (vide adiante, no item II.4, sobre o conceito de sanção). Portanto, toda vez que o Poder Judiciário decreta a nulidade de uma lei ou ato do poder público, por inconstitucionalidade, em face de um princípio constitucional está, em verdade, declarando a incidência do princípio da supremacia da Constituição e aplicando a sanção adequada ao ato de violação. O mesmo ocorre quando edita norma para regular a omissão do poder público em dar efetividade a princípio. (Pode parecer incorreto ou mesmo sem sentido, o considerar como uma sanção a regulação, por ato do Judiciário, de situação jurídica, em havendo omissão do poder público em dar efetividade a princípio constitucional. Entretanto, se considerarmos o conceito amplo de sanção antes referido, chegaremos à conclusão de que, quando o Supremo Tribunal edita a norma reguladora, em substituição ao órgão responsável pela omissão, assume e exerce competência privativa deste, o que, em última análise, constitui uma punição a esse órgão e um modo de impor o poder vinculante do princípio, fazendo cessar a sua violação.)

Além disso, é preciso ter em mente que, em sua grande maioria, repetimos, as normas integrantes dos ordenamentos jurídicos são tão somente especificações dos princípios que os norteiam; vale dizer: a generalidade do conteúdo normativo do princípio é detalhado por meio de normas específicas. Assim, apenas como exemplos, detalham: (a) o princípio constitucional de garantia da propriedade privada (CF, art. $\left.5^{\circ}, \mathrm{XII}\right)$ ), as normas do direito das coisas; (b) o princípio da função social da propriedade $\left(\mathrm{CF}, \operatorname{art.} 5^{\circ}\right.$, $\mathrm{XXIII)}$, as que limitam o uso da propriedade, inclusive as de cunho urbanístico e ecológico (CF, art.225); (c) o princípio da absoluta prioridade da criança e do adolescente (CF, art.227), o ECA e as normas do direito de família; $(d)$ da indenizabilidade do dano material ou moral $\left(\mathrm{CF}, \operatorname{art} .5^{\circ}, \mathrm{V}\right)$, as normas sobre responsabilidade civil; $(e)$ o princípio da privaticidade na sucessão mortis causa $\left(\mathrm{CF}\right.$, art. $\left.5^{\circ}, \mathrm{XXX}\right)$, as do direito das sucessões; (f) o princípio da proteção do consumidor (CF,art. $\left.5^{\circ}, \mathrm{XXXII}\right)$, o CDC; $(g)$ o princípio da universalidade da pretensão à tutela jurídica ("direito de ação", $\mathrm{CF}$, art. 50, XXXV), as normas do processo civil e penal.

Em resumo: porque os princípios, apesar de sua generalidade e indeterminação linguística, atendem aos pressupostos formais e materiais exigidos para a caracterização 
das normas jurídicas, parece indiscutível que não se lhes pode negar caráter normativo e cogência, donde poderem ser violados.

Acrescente-se, para concluir essas observações, que os princípios constitucionais são, além de tudo, dotados de cogência. Assim também, as normas programáticas que, embora muitas vezes não obriguem a realizar o programa, não permitem que se obre contra suas determinações.

\section{II.3.3 Da infração indireta às normas jurídicas}

II.3.3.1. Noções fundamentais. É usual, em doutrina e em julgados, o emprego de expressões como ato em fraude à lei, in fraudem legis agere, fraus legi, para designar o procedimento que, por meios indiretos, aparentemente lícitos, viola norma jurídica cogente, permitindo que se obtenha resultado por ela proibido (norma jurídica cogente proibitiva) ou impedindo que fim por ela imposto se realize (norma jurídica cogente impositiva). Conforme observa Pontes de Miranda (1972, t. I, p. 43), no entanto, é inadequado falar-se de fraude à lei quando se trata de infração indireta à norma jurídica, porque a palavra fraude, cujo conteúdo semântico envolve, necessariamente, intenção de enganar, de burlar, má-fé, conduz doutrinadores e juízes a considerar a intencionalidade como elemento caracterizador da infração indireta da norma jurídica ${ }^{15}$, o que, de modo algum, é verdadeiro (TUHR, 1946, v. III, t.I, p. 10-11; ENNECCERUS, KIPP e WOLFF, 1953, v.2, t.1, p. 303; PONTES DE MIRANDA, 1972, t.I, p. 43). A intromissão da ideia de fraude e, consequentemente, de intencionalidade no conceito de infração indireta da norma jurídica somente tem prejudicado a precisão científica no estudo do tema e a adequação das soluções sempre que se necessita aplicar a espécie.

II.3.3.2. Infração indireta e intencionalidade. Não há dúvida de que a intenção de violar a lei aparentando licitude está presente, em geral, nos atos de infração indireta ( = fraude à lei). Não, porém, com caráter de necessidade. A boa ciência tem demonstrado que a intencionalidade constitui circunstância de todo irrelevante quando se trata de caracterizar a infração indireta da norma jurídica, salvo se a própria norma jurídica a tem como elemento de seu suporte fático. Por se tratar de um modo de infringir a norma jurídica, não importa se foi intencional, de má-fé, fraudulenta (o ocorre na grande maioria dos casos), ou se foi inocente, se o figurante não conhecia a proibição ou a imposição, e, portanto, se agiu de boa-fé, sem a mínima intenção de praticar a infração. $O$ princípio da inalegabilidade da ignorantia iuris para furtar-se a cumprir a lei, tal como consubstanciado nos arts. $3 .^{\circ}$ da Lei de Introdução ao Código Civil e 16 do Código Penal, impõe essa conclusão.

\footnotetext{
${ }^{15}$ Por exemplo: Josserand, Les mobiles dans les actes juridique de droit privé, n.176.
} 
Em verdade, deve-se ter como infringida a lei sempre que o resultado positivo ou negativo a que se destina foi alcançado ou evitado. Não importa quais meios empregados. Não interessa o nome que se der ao fato jurídico, nem é relevante o modo como se procura apresentar a materialidade do suporte fático da norma jurídica, precisamente porque, pelo seu caráter lógico, a incidência se dá fatalmente à simples concreção do seu verdadeiro suporte fático. Por isso, se o ato ou atos praticados pelas pessoas, mesmo que em si sejam lícitos, levaram-nas a alcançar ou evitar resultado proibido ou imposto por norma jurídica cogente, é indiscutível que essa norma incidiu e, assim, indiretamente, foi violada. Por consequência, tem-se que basta a constatação de que o fim positivo ou negativo previsto na norma foi obtido ou evitado para quer se caracterize a infração, direta ou indireta da norma.

O ideal na realização do Direito é que a aplicação da norma coincida com a sua incidência. Como a incidência nunca falha (infalibilidade da incidência), o que pode falhar é a aplicação da norma incidente, porque é ato humano resultante da interpretação da norma e da valoração dos fatos (=suportes fáticos). Por isso, os atos que importam infração indireta à norma jurídica (=fraude à lei), intencionais ou não, não podem ter a pretensão de evitar ou enganar a incidência da norma jurídica, mas visam, isto sim, a burlar a aplicação das imposições normativas, positivas ou negativas, procurando conduzir o intérprete a considerar que outra foi a norma incidente, não a que realmente incidiu e foi infringida. Quer-se obter resultado proibido ou evitar fim imposto pela norma sem que a sanção respectiva lhe seja aplicada. A burla não impede a incidência da norma sobre o suporte fático que realmente se tenha concretizado, mas procura evitar-lhe a aplicação. A infração existe, mas não se quer que seja reconhecida. Por isso, a fraude à lei há de ser examinada, objetivamente, como pura e simples infração à norma jurídica, abstraídos os aspectos psicológicos que possam estar envolvidos. Portanto, para que o intérprete saiba se houve ou não infração, direta ou indireta, à norma jurídica é suficiente verificar se o resultado que a norma proíbe ou impõe foi realizado, independentemente de como seu suporte fático se materializou ou de quantos atos se praticaram.

A falta de compreensão do problema nesses termos e mesmo o conteúdo semântico da palavra fraude, que envolve, necessariamente, intenção de enganar, levou a doutrina menos rigorosa a ver na intenção de contornar a cogência legal, de burlar a lei, dado essencial do conceito da fraus legis, passando-se a exigir a sua prova como essencial à sua caracterização na prática. Essa atitude, além de ter como consequência o permitir confundi-la com figuras como a simulação, o dolo etc., com enormes prejuízos para o perfeito equacionamento do problema da violação indireta da lei, imiscui um elemento complicador que gera a possibilidade de erros na sua aplicação aos casos concretos, fazendo com que sejam exitosas as violações indiretas à normas jurídicas. Isso é particularmente preocupante quando se trata de fraude à Constituição, como veremos oportunamente. 
II.3.3.3. Normas jurídicas passíveis de violação indireta (fraudáveis). Embora todas as normas jurídicas cogentes sejam expostas à violação, nem todas, porém, podem ser objeto de infração indireta, de fraude à lei. Normas jurídicas sobre forma e sobre capacidade, e.g., não podem, em geral ${ }^{16}$, ser fraudadas em razão mesmo da natureza de suas disposições. Se uma compra e venda de imóvel cujo valor seja superior a 30 salários mínimos é formalizada por escritura particular, há infração direta da norma que exige instrumento público. Se se declara que a compra foi realizada por valor inferior aos 30 salários mínimos para furtar-se à escritura pública, não há fraude à lei, mas simulação. A mentira é característica da simulação, nunca da fraude à lei em que os atos são verdadeiros. $\mathrm{O}$ mesmo ocorre quando o menor se declara maior de idade. $\mathrm{O}$ que vicia os atos em fraude à lei é o seu resultado que viola a norma jurídica.

Durante muito tempo afirmou-se, em doutrina, que somente normas jurídicas proibitivas poderiam ser infringidas indiretamente. Esse equívoco vem da influência de leitura de livros antigos inspirados no Direito Romano, que somente conhecia leis proibitivas. Desde o desenvolvimento do Direito Tributário e do Direito Administrativo, ocorrido, notadamente, a partir do Século XX, normas impositivas cogentes passaram a povoar as leis. A partir daí, não resta nenhuma dúvida de que essas normas são sujeitas à violação indireta, destacadamente as tributárias.

Para que uma norma jurídica possa estar sujeita a ser fraudada, portanto, é necessário que tenha caráter de norma impositiva ou proibitiva de resultado, porque o objetivo do ato fraudulento consiste, precisamente, em evitar o resultado imposto ou alcançar o proibido pelas normas jurídicas. Por isso é possível afirmar que somente se a norma jurídica tem por fim impor ou proibir um resultado pode ser objeto de infração indireta.

\section{II.4 DA SANÇÃO JURÍDICA}

\section{II.4.1 Generalidades}

A sanção, consoante mencionado acima, constitui o meio utilizado pelo Direito para tornar efetiva sua coercibilidade e manter íntegra a respeitabilidade do sistema jurídico e a valência de suas normas. Nesse sentido, deve-se entender como sanção toda e qualquer punição que seja imposta ao ato de violação das normas jurídicas, não apenas aquelas que atingem diretamente a vida, a liberdade e o patrimônio das pessoas (=sanções penais), mas, também, as civis, como a invalidade e a ineficácia, que privam os atos jurídicos da possibilidade de gerarem os efeitos jurídicos que lhes são próprios, se lícitos fossem ${ }^{17}$.

\footnotetext{
${ }^{16} \mathrm{~A}$ observação não se aplica às normas formais do processo legislativo previstas na Constituição, que podem ser violadas, conforme mostraremos no local adequado.

${ }^{17}$ Nessa visão das sanções não entram a denominadas sanções premiais de que falam Bobbio e Kelsen (este em relação a normas da ordem social, mas não jurídicas), uma vez que se tem por sanção apenas penalidades, 
A problemática das sanções se põe na dimensão dogmática do Direito. Sanção é instrumento terapêutico para combater os estados teratológicos sociais representados pela violação das normas do direito. Cada comunidade jurídica as elege segundo seus valores, suas necessidades, conveniência e adequação aos fins a que se destinam, considerando as situações que ocorrem em seu meio. Nessa escolha há como que uma quase arbitrariedade, somente limitada pela natureza das coisas e a dignidade do ser humano. Porque as sanções variam de sistema jurídico a sistema jurídico e, mesmo no seio do próprio sistema jurídico em relação a fatos semelhantes, segundo certas peculiaridades, não é possível dar-lhes um tratamento sistematizado, muito menos construir sobre elas uma concepção universalizada que generalize os conceitos e permita a elaboração de uma teoria geral das sanções. Assim, cada sanção há de ser estudada particularizadamente em cada sistema jurídico.

Em face disto, inicialmente é necessário anotar que há normas jurídicas em cuja estrutura proposicional estão previstas sanções para a hipótese de virem a ser violadas (pena de reclusão ao homicídio, v.g.). São as sanções específicas. Todas as normas jurídicas que definem crimes e contravenções penais, bem como quaisquer outras que prevejam alguma penalidade para os atos que as infringem, contêm sanções que se enquadram nessa categoria. A par dessas, existem ínsitas nos sistemas jurídicos sanções inespecíficas ( = que não estão relacionadas, expressamente, a uma conduta determinada) as quais, além de cumprirem a função de garantir sua valência como um todo, se destinam a assegurar, em particular, a impositividade das normas que não preveem sanções próprias, específicas, para punir as condutas que as violem. Por meio das sanções inespecíficas, universaliza-se a coercibilidade dentro do sistema jurídico, de modo que todas suas normas são coercitivas, independentemente de que contenham, em sua estrutura proposicional, previsão de uma punição específica para o caso de serem infringidas. A invalidade é exemplo dessas sanções que, genericamente, estão presentes nos sistemas jurídicos para garantir sua coercibilidade.

Para o presente estudo, porque relacionado diretamente à inconstitucionalidade de leis e atos normativos, as sanções que interessam são as de natureza civil, especialmente a invalidade e outras aplicáveis à espécie.

\section{II.4.2. As sanções civis à infração direta às normas jurídicas}

No que diz respeito à contrariedade direta às normas jurídicas, nas áreas cíveis ( = não penais), tanto no direito público, como no direito privado, a invalidade constitui

portanto, um conceito estrito e não lato. Essa ideia de sanção não é aceita com unanimidade. Autores como Bobbio e Hart negam possam a invalidade e a ineficácia ser consideradas sanções. Essas objeções e a justificação do ponto de vista aqui defendido estão discutidas em nossos livros Teoria do fato jurídico: plano da existência e Teoria do fato jurídico: plano da validade. Não serão aqui apreciadas, em razão do espaço de que dispomos, considerando que exigem uma discussão relativamente longa. 
a sanção própria e mais usual (as de privação de eficácia jurídica são mais raras) aplicável. No Direito brasileiro, dois são os graus de invalidade, a saber:

(a) nulidade, sanção mais enérgica e de consequências mais graves em razão de as normas que protege apresentarem mais acentuado interesse público do que aquelas asseguradas pela

(b) anulabilidade cujo principal objeto consiste em resguardar a higidez da vontade dos figurantes na prática de atos jurídicos, ou simplesmente preservar pessoas de menor capacidade de discernimento ou expostas a situações de fragilidade.

No campo do Direito Constitucional, ao menos em nosso sistema jurídico, a anulabilidade não tem maior importância, mas, sim, a nulidade, uma vez que doutrina e jurisprudência são praticamente unânimes em afirmar que essa é a sanção própria para a inconstitucionalidade das leis, atos normativos e atos jurídicos de direito público em geral $^{18}$. Por isso, somente a ela nos dedicaremos.

Segundo o critério de estarem previstas, expressamente, em texto legislativo, ou não, as nulidades podem ser classificadas em:

(a) nulidade textual, expressa ou cominada, quando vem taxativamente declarada na lei (Código Civil, art. 166, VII, primeira parte; CPC, art. 243); e

(b) nulidade virtual ou não-cominada (Código Civil, art. 166, II, III e VII, segunda parte; CPC, arts. 244), que resulta da violação de norma jurídica cogente, proibitiva ou impositiva, que, sendo silente quanto à sanção da nulidade, não define outra espécie de sanção para o caso de ser transgredida (= sanção inespecífica).

Se a norma jurídica declara nulo certo ato ou lhe nega efeito (= nulidade textual), não há, aparentemente, maiores dificuldades quanto a aplicar-lhe a sanção de nulidade; bastará que o ato concretize a situação fática prevista na norma para que seja nulo.

Quando, no entanto, se trata de nulidade virtual, não cominada, a solução dos casos não é tão simples. Inicialmente, é necessário levar-se em conta que nem toda norma jurídica cogente tem a nulidade como consequência para o caso de sua violação. Por isso, não é correto afirmar-se, genericamente, que a violação de norma cogente tem sempre a nulidade como sanção, porque depende de como a própria norma jurídica trata a infração. A assertiva somente é verdadeira nas hipóteses de não haver norma jurídica que preveja outra penalidade específica para o ato que a infrinja, como se pode concluir da norma do art. 166, VII, do Código Civil. O princípio é o de que a sanção inespecífica somente é aplicável se houver omissão normativa quanto à penalidade aplicável à sua infração; se há sanção especifica, qualquer que seja, não há possibilidade ter-se por nulo o ato jurídico que a viole.

${ }^{18}$ Há outras técnicas para tratar a inconstitucionalidade, como a interpretação segundo a Constituição, com ou sem redução de texto, e a edição de normas para regulação de casos concretos, nas hipóteses de inconstitucionalidade por omissão. 
No Direito Processual, a questão de ser, ou não, cominada a invalidade tem implicações diferentes, uma vez que, havendo a norma jurídica prescrito certa forma, sem, contudo, especificar a sanção da invalidade para o seu desatendimento, deve-se considerar válido o ato, se alcançou a finalidade processual, sem prejuízo para qualquer das partes (CPC, arts. 244 e 250, parágrafo único).

No plano constitucional, as invalidades são sempre virtuais. Não há nos textos constitucionais normas que cominem a sanção de nulidade, ou outras, a específicos atos jurídicos, em especial a atos legislativos infraconstitucionais ${ }^{19}$. As sanções aplicáveis aos casos de inconstitucionalidade de leis e outros atos normativos, quer sejam de nulidade quer de outra natureza, são não cominadas. (Das questões relativas à inconstitucionalidade trataremos adiante, no momento adequado.)

As questões não são tão simples quando se trata de invalidade por violação indireta das normas jurídicas.

\section{II.4.3 Da sanção à violação indireta das normas jurídicas}

Tendo-se como premissa que o denominado ato em fraude da lei constitui, em verdade, um modo de infração às normas jurídicas, parece evidente a conclusão de que, de lege ferenda, a sanção a ele aplicável deve ser a mesma cabível para o caso de violação direta. A lógica deve presidir os sistemas jurídicos e nada mais ilógico do que, em se considerando dois atos contrários à mesma norma jurídica, sendo um direto, claro, sem artimanhas maliciosas, e o outro indireto, embuçado, cercado de artifícios, aplicar-lhes penalidades diferentes.

No caso de sanção de invalidade, não deve importar se a violação foi direta ou indireta (fraude à lei). Em qualquer situação, seja textual ou virtual a sanção, se a pena para a infringência for a nulidade, deveria ser ela aplicada a qualquer ato jurídico que as viole direta ou indiretamente. Se, diferentemente, a sanção for de anulabilidade, anulável deveria ser o ato de infração indireta. No entanto, o Legislador Civil de 2002, adotando posição que demonstra falta de domínio sobre o instituto, definiu a fraude à lei como causa de nulidade, genericamente ${ }^{20}$. Essa atitude criou a absurda possibilidade de soluções diferentes para situações iguais ${ }^{21}$, o que nos parece de todo inadequada.

${ }^{19}$ Anotem-se, como exceções, a referência da nulidade dos atos lesivos a patrimônio público ou de entidade de que o Estado participe, à moralidade administrativa, ao meio ambiente e ao patrimônio histórico e cultural (art. $5^{\circ}$, LXXIII), e dos atos que tenham por objeto a ocupação, o domínio e a posse de terras indígenas ou a exploração de suas riquezas naturais ( $\left.\operatorname{art} .231, \S 6^{\circ}\right)$.

${ }^{20}$ Naturalmente dentro daquele quase arbítrio que o legislador tem na definição da eficácia jurídica, inclusive relativa às sanções, conforme anotamos no texto.

${ }^{21}$ Veja-se, como exemplo, a espécie prevista no art.496 do Código Civil. Segundo esse dispositivo é anulável a venda de ascendente a descendente sem o consentimento dos demais descendentes e do cônjuge do 
$\mathrm{O}$ correto tratamento da sanção aos atos em fraude à lei deve ser o de imputar-se a eles a mesma penalidade prescrita para a infração direta.

\section{II.5 CONCLUSÕES EM RELAÇÃO ÀS PREMISSAS SOBRE INFRAÇÃO DAS NORMAS JURÍDICAS}

Postas essas premissas teóricas, podemos concluir que:

(a) as normas jurídicas, em razão de sua obrigatoriedade e da circunstância de serem uma imposição da comunidade aos indivíduos, estão sempre expostas à violação pela conduta contrária das pessoas, desde que estas são dotadas de livre arbítrio;

(b) apesar disto, mesmo quando violadas, as normas jurídicas não perdem sua valência, mantendo-se vigentes e vinculativas dentro do sistema jurídico;

(c) por duas maneiras as norma jurídicas podem ser violadas: diretamente ou indiretamente (fraude á lei). As duas maneiras de infringir as normas jurídicas têm o mesmo resultado, distinguindo-se uma da outra apenas pelo modo de agir do infrator: enquanto na infração direta age-se sem subterfúgios que procuram mascara-la, na fraude à lei são utilizados expedientes aparentemente lícitos com que se busca dar aparência de legitimidade aos atos infringentes da norma;

(d) o Direito necessita de manter-se íntegro e assegurar a respeitabilidade de suas normas, o que procura fazer por intermédio da coercibilidade externa que impõe às pessoas as condutas queridas pela comunidade;

(d) as sanções constituem os instrumentos utilizados pelo Direito para efetivar sua coercibilidade e, por meio dela, obter a integridade do sistema jurídico;

(e) na definição do conteúdo das sanções, a comunidade jurídica dispõe de liberdade tão ampla que mais se assemelha a arbítrio, somente limitado pela natureza das coisas e a dignidade do ser humano;

(f) por isso, as sanções variam no tempo e no espaço, de sistema a sistema jurídico, segundo os valores de cada comunidade jurídica, motivo pelo qual não há paradigmas a serem obedecidos, nem a possibilidade de elaboração de uma teoria que generalize e universalize conceitos sobre elas;

(g) no entanto, a logicidade que deve presidir os sistemas jurídicos impõe que na definição das sanções seja obedecida uma certa coerência, em razão do que para a mesma infração de normas jurídica se deve imputar a mesma sanção, independentemente da maneira como se tenha efetuado: direta ou indireta.

alienante, salvo, quanto a este, se forem casados pelo regime da separação obrigatória de bens, decaindo em dois anos, a contar do registro, a pretensão para anular a venda feita com infringência dessa proibição. Se, no entanto, ao invés de vender diretamente ao filho, o pai vende o bem a terceiro que, por sua vez, o vende ao filho, haverá fraude à lei, em razão da qual o negócio jurídico é nulo e imprescritível a ação para anulá-lo. Como se vê, para a infração da mesma norma jurídica o legislador adotou sanções diferentes, apenas em face do modo como se realizem, em opção absolutamente incoerente e inadequada. O correto seria dispor que ao ato praticado em fraude à lei cogente aplica-se a mesma sanção imputada ao ato de infração direta. 


\section{PREMissas EM RELAÇÃo À VIOLAÇÃo de nORMas E PRINCíPIOS CONSTITUCIONAIS POR LEIS E ATOS NORMATIVOS}

\section{III.1 O PRINCÍPIO DA SUPREMACIA CONSTITUCIONAL E O CONTROLE DA CONSTITUCIONALIDADE DAS LEIS E DOS ATOS DO PODER PÚBLICO}

A Constituição, em razão de sua função de organizar ${ }^{22}$ o Estado, de estruturá-lo, política e juridicamente, definindo seus poderes, devolvendo entre eles as competências para exercê-los, bem como fazendo o traçamento das relações entre os súditos e o príncipe, constitui o mais importante instrumento normativo de uma comunidade jurídica, fonte de onde emanam a legitimidade e a valência de seu sistema jurídico como um todo e de cada uma de suas normas, em particular. Em face desse seu caráter, existe ínsito nos sistemas jurídicos, o princípio da supremacia constitucional que, de modo absoluto, garante sua prevalência sobre todo o sistema jurídico e suas normas. Apesar disto, apesar de ao poder público outorgar-se a missão de guarda da Constituição, ele próprio, não raras vezes, costuma desrespeitá-la sempre que suas normas lhe criam obstáculos a que alcance seus desígnios. A violação das leis fundamentais (= Constituições) é uma constante na história. Incessante e permanentemente, a humanidade tem lutado para ver efetivada na realidade social a ideia de que todos, inclusive e principalmente o príncipe $(=0$ estado), estão subordinados a leis superiores.

Conforme registra a história, encontra-se na graphé paranomón, instituída em Atenas pelo gênio de Péricles, a primeira manifestação no sentido do reconhecimento de uma supremacia de lei fundamental e em razão dela manter-se o controle sobre os atos do poder público e do próprio povo ${ }^{23}$.

${ }^{22}$ Costuma-se dizer, em doutrina, que a Constituição constitui (=cria) o estado. Entretanto, a nosso ver, essa assertiva, cientificamente analisada, contém grave incorreção. Em verdade, a circunstância da adoção de uma Constituição por certa comunidade por si só não cria o estado, se não houver o seu reconhecimento como tal pela comunidade internacional, segundo as regras do direito das gentes. Em rigor, é preciso considerar que, do ponto de vista jurídico, o estado não é mais do que uma pessoa jurídica do direito das gentes (= pessoa jurídica na ordem internacional) cuja existência resulta da eficácia de um fato jurídico do direito das gentes que tem no reconhecimento por outros estados o elemento cerne de seu suporte fático (sobre elementos do suporte fático, vide nosso Teoria do fato jurídico: plano da eficácia, §31, 3.1.) Não basta, portanto, isto é indiscutível, que a comunidade decrete uma Constituição para que uma comunidade politicamente organizada se transforma em estado. Enquanto reconhecimento não houver, estado não há. Por isso, parece-nos correto afirmar, como fizemos no texto, que a Constituição é instrumento através do qual se organiza o estado, estrutura-o, política e juridicamente, definindo seus poderes, devolvendo entre eles suas competências e traçando as relações entre ele e seus súditos.

${ }^{23}$ Tratava-se de uma ação criminal por inconstitucionalidade cuja eficácia consistia em suspender a validade de um decreto mesmo depois de já haver sido aplicado em juízo. O tribunal constituído de 1.000 jurados, e algumas vezes de 6.000, se reunia sob a presidência de tesmótetas, magistrados atenienses que tinham a incumbência de guarda e observância das leis Sobre esse instituto, vide nosso Breve pesquisa sobre a história da supremacia constitucional, in Revista da Consultoria Geral do Estado de Alagoas, ano I, n.1, p. 37 s., e Liñares Quitana, Tratado de la ciência del derecho constitucional argentino y comparado, t. II, p. 251 s.Buenos Aires, Alfa, 1953. 
O estado romano conheceu leis constitucionais. O vocábulo Constituição mesmo teria seu étimo na expressão rem publicam constituere com que as definiam. Mas, apesar disto, apesar da distinção que faziam entre Constituição do Estado e disposições legislativas particulares (PINTO FERREIRA, 1983, I, p. 58), não há indicações de ter havido preocupação de seus juristas em afirmar a supremacia daquelas normas sobre as atividades estatais, muito menos em adotar meios de controle para preservá-la.

No século XII, na Inglaterra, Henry Bracton, Juiz do King 's Bench, já afirmava o postulado de que o rei não se acha sujeito aos homens, senão a Deus e à lei (BLEDEL, 1947, p. 6).

Na Espanha, em 1283, os grandes proprietários espanhóis impuseram ao Rei Pedro o Privilegium generale aragonum que estipulava,"Primeiramente, que o senhor rei observe e confirme fueros, usos, costumes, privilégios, cartas de doações, câmbios dos reinos de Aragon, de Ribagorza, de Valencia e de Teruel", conforme anota Liñares Quintana (1953, p. 254). Isso transformou os fueros em verdadeira lei constitucional que, igualmente, deveria ser respeitada pelo rei e pelo povo.

Na França, antes mesmo do século XVI, quando a doutrina se consolidou, já se fazia a distinção entre leis do rei e leis do reino; estas últimas, também denominadas leis fundamentais e até mesmo constitucionais, eram regras, em geral costumeiras, que se impunham ao rei detentor do poder legislativo. O rei, legislador ordinário, não as pode modificar ou ab-rogar, senão com a aprovação dos estados gerais ${ }^{24}$.

Mas é preciso destacar que as leis fundamentais em França tinham por objetivo exclusivo o Estado especialmente visando à unidade, à perpetuidade e à independência do Estado real e a salvaguarda da monarquia. Não havia, à evidência, uma preocupação com a salvaguarda das relações entre o Estado e os indivíduos, mesmo porque disso as leis fundamentais (constitucionais) não cuidavam. Diferentemente, na Inglaterra, como vimos, bem antes mesmo da elaboração doutrinária francesa, já se podia identificar o embrião da supremacia das leis constitucionais, ainda mais com a conotação especial de uma garantia do súdito contra o príncipe.

Apesar dessas manifestações sobre a superioridade de certas normas em relação à legislação ordinária, é possível afirmar que o princípio de supremacia constitucional teve, pela primeira vez, sua consagração em texto constitucional no enunciado do art. VI, cláusula 2, da Constituição Norte-Americana; in verbis:

2. Esta Constituição e as leis complementares e todos os tratados já celebrados ou por celebrar sob a autoridade dos Estados Unidos constituirão a lei suprema do país; os juízes de todos os

${ }^{24}$ Leon Duguit, Traité de droit constitutionnel,v.III, p.691. No mesmo sentido, Paul Ourliac, Historia del derecho, v. II, p.183, e Prelot, Précis de droit constitutionnel,p. 53 
Estados serão sujeitos a ela, ficando sem efeito qualquer disposição em contrário na Constituição ou nas leis de qualquer dos Estados ${ }^{25}$.

As circunstâncias históricas relatadas demonstram tão somente uma preocupação em ressaltar o império da lei e a existência de leis superiores a que estariam subordinados os soberanos, exceto no caso grego em que se buscava um controle da compatibilidade dos atos do poder público e dos particulares em face das leis consideradas fundamentais. É evidente, porém, que a supremacia constitucional somente tem significado quando há um controle das leis e dos atos públicos por órgão especializado que recuse validade àqueles que infrinjam normas da Constituição. Nesse sentido, abstraindo a graphé paranomón, a primeira e mais importante manifestação nesse sentido encontra-se na doutrina de Coke, produzida no primeiro terço do século XVII, que, como também presidente do King 's Bench (cargo de foi demitido pelo rei James I), utilizou-se daquela citada máxima de Henry Bracton para, no famoso caso do Dr. Bonham, esclarecer:

Conforme resulta de nuestros libros el common law controlará las leyes del Parlamento y a veces las declarará insanablemente nulas; porque cuando una ley del Parlamento es contraria al derecho común (common right), a la razón, y repugnante o de imposible realización, el common law la controlara y declarara que dicha ley es nula. (BLEDEL, 1947, p. 7)

Com fundamento nessa doutrina, os juízes ingleses, em luta contra o absolutismo real, insurgiram-se desde aí contra a possibilidade de modificação abusiva da common $l a w^{26}$. Entretanto, somente com a instituição no sistema constitucional americano do

${ }^{25}$ Clause 2.This Constitution and the Laws of The United States which shall be in Pursuance thereof; and all Treaties made, or which shall be made, under the Authority of the Land; and the Judges in every State shall be bound thereby, any thing it the Constitution or Laws of any State to the contrary notwithstanding. Este dispositivo, conforme informa Corwin (A Constituição norte-americana e seu significado atual, p.215) é considerado the linch pin of the constitution (o ponto nodal da Constituição) dos Estados Unidos da América.

${ }^{26}$ A obra de Coke teve decisiva importância para a consolidação das instituições do estado inglês. Há quem lhe atribua uma expressão relativa apenas ao judicial control, mas, em verdade, a maior ênfase de seu esforço foi sempre no sentido de definir o primado da lei e estabelecer o princípio supremo do sistema constitucional inglês que é o da supremacia do Parlamento. De sua atuação como membro do Parlamento, resultou a Petition of Rights de 1628, em razão da qual, com a sua sanção, o Rei,“se obligó a no gravar con impuestos ni percibirlos sin el consentimiento del Parlamento, a no encarcelar a nadie sin el debido procedimiento legal y a no someter a los ciudadanos a la jurisdicción de las cortes marciales y si, en cambio, a los tribunales ordinarios del Reino, reservandose expresamiente su derecho de la prerrogativa" (Bledel, Introducción al estúdio del derecho publico anglosajón, cit.p. 9).

Além disto, a sua interpretação da Magna Carta, de caráter jurídico, é que ressaltou e fixou, definitivamente, a natureza legislativa daquele documento e, como decorrência, determinou a extensão de seus favores e garantias a todo o povo inglês, porque, até então, era ela considerada apenas um acordo dos senhores feudais com o rei e, portanto, somente a eles protegeria.

Sua doutrina, no entanto, de que o judiciário fosse um guardião das leis fundamentais do reino, não conseguiu vingar, sendo certo que essas suas ideias foram abandonadas em consequência das revoluções de 1640 e 1688, e do princípio da supremacia do parlamento, que torna as leis por ele editadas superiores aos precedentes judiciais, consideradas as mais importantes fontes do common law. 
judicial control (judicial review), também inspirado na doutrina de Coke e positivado na cláusula 2 do art. III, da Constituição de $1787^{27}$, mediante o qual se atribuiu ao Judiciário, em especial à Suprema Corte, o poder de controlar a constitucionalidade das leis e dos atos do poder público, declarando-os nulos quando conflitantes com disposições constitucionais, e a importância que lhe deu a doutrina, é que a supremacia constitucional se viu elevada à classe de "problema fundamental no direito constitucional moderno" (CAMPOS, 1956, I, p. 432).

Como podemos constatar, o problema da inconstitucionalidade das leis e atos do poder público constitui uma permanente preocupação da comunidade jurídica.

\section{III.2 A VIOLAÇÃO DO PRINCÍPIO DA SUPREMACIA CONSTITUCIONAL COMO FUNDAMENTO ÚLTIMO DA INCONSTITUCIONALIDADE}

Vários doutrinadores costumam tratar a inconstitucionalidade dos atos normativos infraconstitucionais (=emendas constitucionais, leis de qualquer espécie e outros atos normativos, em geral) como um problema de Lógica Jurídica, relacionando-o à consistência do sistema jurídico, ao argumento de que não seria admissível que uma norma de nível hierárquico inferior pudesse existir dentro do ordenamento em conflito com uma norma constitucional, hierarquicamente superior. Em verdade, porém, esse modo de conceber a inconstitucionalidade como caso de antinomia nos parece equivocada. Se bem analisada a questão, chegar-se-á à conclusão de que essa matéria se põe no plano da infração às normas jurídicas e não se cinge a simples problema de antinomia, consoante será demonstrado a seguir.

Em boa ciência, a explicação que se dá de um fenômeno, qualquer que seja, há de ser suficiente para incluir todos os seus aspectos, de modo que é inconsistente quando não consegue defini-lo em sua total abrangência, deixando de fora alguma de suas facetas, uma que seja. A regra científica não pode admitir exceções; se há exceções, a regra adequada não foi encontrada. No caso da decretação ${ }^{28}$ de inconstitucionalidade de leis

${ }^{27}$ In verbis: Clause 2: The judicial Power shall extend to all Cases, in Law and Equity, arising under this Constitution, the Laws of the United States, and Treaties made, or which shall be made, under their Authority;--to all Cases affecting Ambassadors, other public Ministers and Consuls; to all Cases of admiralty and maritime Jurisdiction;--to Controversies to which the United States shall be a Party; to Controversies between two or more States; between a State and Citizens of another State; between Citizens of different States, between Citizens of the same State claiming Lands under Grants of different States, and between a State, or the Citizens thereof, and foreign States, Citizens or Subjects.

${ }^{28}$ É usual em doutrina, legislação e jurisprudência, o emprego da expressão declaração de inconstitucionalidade para designar o ato pelo qual um tribunal reconhece que uma determinada lei é inconstitucional. A expressão, em rigor técnico, é inadequada. Com efeito, a decisão sobre inconstitucionalidade tem a eficácia de 
e atos normativos, o considerá-la uma forma de resolver antinomias entre normas de hierarquias diferentes, sendo uma constitucional, não a explica em todos os pormenores de sua realidade. Senão, vejamos.

Nos sistemas jurídicos de direito escrito com Constituições rígidas há duas espécies de inconstitucionalidades a considerar: $(a)$ material e $(b)$ formal ${ }^{29}$. (a) Diz-se material a inconstitucionalidade quando norma jurídica infraconstitucional, ou ato administrativo, conflita com norma jurídica constitucional, quanto a seu conteúdo normativo. Se, por exemplo, a Constituição proíbe a admissão de servidor público sem concurso público, é materialmente inconstitucional uma lei que permita admissão de pessoal sem concurso. (b) Formal é a inconstitucionalidade quando, no procedimento para a elaboração de espécie legislativa, mesmo de emenda constitucional, houver violação de norma do processo legislativo previsto na Constituição. Exemplificando: a autoridade que sancionou a lei não tinha poder para sancioná-la; quem teve a iniciativa de propor o projeto de lei não tinha competência para fazê-lo; o quorum que o aprovou não foi o previsto na Constituição; regulamentou-se por meio de lei ordinária matéria reservada à lei complementar. Em havendo situações como essas, a emenda constitucional, a lei ou o ato normativo é formalmente inconstitucional. Embora pouco se estude a inconstitucionalidade formal, não há dúvida, em boa doutrina, quanto à sua existência, como já o reconheceu por várias vezes o STF.

desconstituir a lei ou o ato por ela atingido, portanto, reconhece que a lei ou ato existe, mas é inválido, motivo pelo qual o desfaz (=desconstitui). Em boa terminologia processual, declaração é termo que se refere à existência ou inexistência de situação jurídica ou à falsidade ou veracidade de um documento, sendo, assim, inadequado quando se trata de invalidade. Daí se tira que a decisão que constata a inconstitucionalidade é, por natureza, uma decisão desconstitutiva (= constitutiva-negativa, na linguagem de Pontes de Miranda), donde não poder ser ao mesmo tempo declarativa (=declaratória). É evidente que para desconstituir a lei ou o ato é preciso que haja uma declaração em que se reconhece existir a inconstitucionalidade, mas essa é apenas, digamos, preparatória da desConstituição. Examinada a questão sob a óptica da concepção ponteana das cinco cargas eficaciais das sentenças (constitutiva, declarativa, condenatória, executiva e mandamental), segundo a qual todas as sentenças têm as cinco eficácias, com maior ou menor força eficacial, e são classificadas em razão da eficácia predominante, tem-se que na decisão que invalida a lei ou ato inconstitucional predomina a carga desconstitutiva (5) seguida da carga declarativa (4). Diferentemente, a decisão que reconhece que a lei ou ato não é inconstitucional tem carga predominantemente declarativa (5) precisamente porque apenas declara a inexistência de incompatibilidade com a Constituição; portanto, não cria (= constitui), nem desfaz (= desconstitui) a lei ou o ato. Em face disto, parece-nos ser inadequado falar em declaração de inconstitucionalidade, mas em decretação de inconstitucionalidade, sendo de todo correto dizer-se declaração de constitucionalidade.

${ }^{29}$ Há doutrinadores que se referem a inconstitucionalidade (a) direta, ou imediata, quando a lei ou outro ato normativo da mesma hierarquia infringe a Constituição, e (b) indireta, ou mediata, quando norma jurídica infralegal (um decreto regulamentar, uma resolução de tribunal, e.g.) ou ato administrativo viola uma norma de lei ou ato normativo de igual hierarquia, ao argumento de que a norma infralegal ou ato administrativo estaria, de fato, violando indiretamente a Constituição que deu ao administrador a competência para executar as leis e não para legislar, o que aconteceria quando se edita norma ou ato administrativo contrário à lei. Essa doutrina, apesar de parecer fundada em raciocínio lógico impecável, leva ao absurdo de, na prática, dar status de matéria constitucional a todo e qualquer ato de violação de lei por ato normativo infralegal ou ato administrativo, abrindo-se margem à sua apreciação pelo STF por via de recurso extraordinário. A Corte Suprema já rejeitou por várias vezes essa doutrina. 
Parece-nos de todo evidente que nos casos de inconstitucionalidade formal não se estabelece antinomia alguma entre uma norma constitucional e a norma infraconstitucional. Há, sim e tão somente, violação da norma constitucional reguladora do processo legislativo, aí compreendidas as atividades de constituinte derivado, cuja força vinculativa vem do princípio da supremacia constitucional. Daí se conclui, necessariamente, que, se no universo das inconstitucionalidades há delas que não resultam de antinomia, não é possível erigi-la a causa de inconstitucionalidade, ao menos com caráter de generalidade.

Mas, quando se trata de inconstitucionalidade material, não haveria antinomia entre a norma infraconstitucional e a legal? Só aparentemente, é a resposta. Se não há antinomia, donde resultaria a inconstitucionalidade? Se bem analisada a questão, tem-se que a inconstitucionalidade material decorre de violação do princípio da supremacia constitucional. Realmente, nos sistemas de direito escrito, em que vige esse princípio, a Constituição é a lei suprema do estado, estando a ele sujeitos tudo e todos que se encontrem em seu âmbito de valência. Em razão dele, cria-se no sistema jurídico uma gradação hierárquica em que as normas da Constituição são sempre superiores a quaisquer outras normas e atos do poder público. Uma implicação incontornável desse princípio consiste na proibição dirigida a todos os poderes constituídos do Estado de atuarem, em quaisquer áreas de suas competências, de modo que infrinjam os ditames constitucionais. Diante disso, um exame mais acurado do problema revela que, em essência, tanto no caso de inconstitucionalidade material, como na hipótese de inconstitucionalidade formal, o que se tem são situações em que há violação do princípio da supremacia da Constituição, uma vez que, quando se o infringe alcança-se resultado proibido pela Constituição.

Assim, parece-nos que não há falar em antinomias como causas de inconstitucionalidade e muito menos ver na invalidação da norma inconstitucional, ou em sua interpretação conforme a Constituição, com ou sem redução de texto, técnicas para resolvê-las. A questão da inconstitucionalidade, sem dúvida, cinge-se a casos de violação de princípio constitucional cogente, donde situar-se em dimensão puramente dogmática que, naturalmente, como todas em Direito, tem arraigado fundo axiológico.

\section{III.3 MODOS POSSÍVEIS DE VIOLAR A CONSTITUIÇÃO}

Conforme mostramos no item II.3.1, acima, as normas da Constituição, como quaisquer outras normas jurídicas, podem ser violadas direta ou indiretamente ${ }^{30}$. Infringe

${ }^{30} \mathrm{O}$ emprego dos advérbios diretamente e indiretamente nada tem a ver com as inconstitucionalidades ditas diretas, ou imediatas, e indiretas, ou mediatas, a que nos referimos na nota n.37, mas à circunstância de ser realizada sem rebuços nem ardis ou com o uso desses expedientes com a finalidade de dar aspecto de legitimidade ao ato inconstitucional. 
diretamente a Constituição a lei, ato normativo ou ato do poder público que conflita com suas disposições (=inconstitucionalidade material), bem assim a edição de lei ou ato normativo em cujo procedimento de elaboração tenha havido desrespeito a norma do processo legislativo constitucional (=inconstitucionalidade formal). Indiretamente, infringe-se a Constituição quando, dispondo de maneira aparentemente com ela compatível, a lei, o ato normativo ou o ato administrativo alcança resultado por ela proibido ou evita o fim por ela imposto ${ }^{31}$ (transplantando a terminologia usual no direito privado, temos fraude à Constituição). Em geral, a infração da norma constitucional se dá frontalmente, diretamente, sem rebuços. Nesses casos de infração direta, a simples comparação das disposições da lei e do ato normativo com a norma constitucional revela a incompatibilidade entre os dois. Diferentemente, nas hipóteses de infração indireta (=fraude à Constituição) a constatação da inconstitucionalidade exige atividade hermenêutica bem mais complexa. Em geral, nesses casos, para encobrir o real sentido da lei ou ato normativo a ele se adicionam dados que buscam mudar-lhe a fisionomia para lhe dar aparência de legitimidade. Assim, no exame da constitucionalidade da lei é preciso, antes, desvesti-la de todos os disfarces que lhe foram apostos para, então, poder identificar sua verdadeira estrutura normativa e, daí, poder avaliar se, de fato, é ou não compatível com os fins da Constituição (conforme anotamos no item II.3.3.2, os atos ditos em fraude à lei [=violação indireta da norma jurídica] têm o objetivo de encobrir a realidade do seu conteúdo para, pela aparência de legitimidade de que se procura dotá-lo, fazer com que o juiz erre, deixando de aplicar a norma efetivamente incidente. Por isso, se da análise da norma infraconstitucional, escoimando-a das aparências que lhe são adicionadas, resulta que, em sua essência, infringe preceito constitucional, nos parece de todo pertinente afirmar que a violação indireta da Constituição deve ser tratada como a violação direta, implicando, necessariamente, a aplicação da sanção de inconstitucionalidade com todas suas consequências relativas à sua validade e eficácia.

\section{III.4 AS SANÇÕES PARA A INCONSTITUCIONALIDADE}

A doutrina clássica nacional, sob a influência da norte-americana do judicial control, entendia que a nulidade com eficácia ex tunc constituía a sanção para a inconstitucionalidade das leis e atos dos poderes estatais. Esse entendimento era

${ }^{31}$ Parodiando a célebre definição de Paulo, pode-se dizer que faz contra a Constituição aquele que faz o que a Constituição proíbe ou evita o que ela impõe, em fraude a ela aquele que, respeitando as suas palavras, o seu sentido elude. 
pacífico $^{32}$. Algumas raras vezes, porém, atendendo a peculiaridades fáticas dos casos, o STF, em caráter de exceção, atribuía eficácia ex nunc à sua decisão ${ }^{33}$.

A doutrina construída pelo STF após a Constituição de 1988 e a edição das Leis n. ${ }^{\circ}$ 9.868, de 10.11.1990, e n. ${ }^{\circ}$ 9.882, de 3.112.1999, que ampliaram de modo significativo o tratamento dado à inconstitucionalidade das leis e dos atos normativos, aperfeiçoou-se de maneira notável, tornando mais racional e útil o controle da constitucionalidade. O reconhecimento da existência de inconstitucionalidades por omissão e do poder de editar norma para supri-las, in casu; a admissão de competência para a suspensão cautelar da norma inconstitucional; o acolhimento de inconstitucionalidade por violação de princípio constitucional; a exclusão do caráter de excepcionalidade que havia na concessão de eficácia ex nunc à nulidade da lei ou ato normativo inconstitucional, tornando-a ordinária; a adoção de outras formas de corrigir as infrações à Constituição, como dar à lei interpretação segundo a Constituição, com ou sem redução de texto, são exemplos desses aperfeiçoamentos ${ }^{34}$.

\section{O PROBLAMA DA INFRAÇÃo INDIRETA DA CONSTITUIÇÃo (FRAUDE À CONSTITUIÇÃO)}

\section{IV.1 ANÁLISE SOBRE A POSSIBILIDADE E EFETIVAÇÃO DE INFRAÇÕES INDIRETAS DA CONSTITUIÇÃO}

Apesar de militar em favor dos atos do poder público, segundo a doutrina dominante, o princípio da presunção de legitimidade e de validade dos atos do poder público, não é incomum a prática de atos legislativos e executivos em violação de preceitos constitucionais, para atender a interesses políticos ou ocasionais. O fato de o STF estar abarrotado de ações diretas de inconstitucionalidade e de recursos extraordinários que contestam leis, atos normativos e atos da administração por infringentes de preceitos constitucionais, bem demonstra a relatividade daquele princípio. Em geral, essas violações da Constituição são diretas. Mas, também, há muitas que resultam de infrações indiretas, de fraudes a preceitos constitucionais. Senão, vejamos alguns casos exemplares, espécimes mais eloquentes de fraus constitutionis constatáveis em nosso sistema político.

${ }^{32}$ Não teve eco na doutrina brasileira a opinião de Hans Kelsen, segundo as quais as leis inconstitucionais seriam apenas anuláveis.

${ }^{33} \mathrm{Em}$ casos de aumentos de vencimentos do funcionalismo considerados inconstitucionais em que, face à circunstância de ser impossível restituir ao servidor o trabalho despendido, dispensava-se a devolução dos salários recebidos até a data da decisão, em respeito do princípio de que a ninguém é dado enriquecer sem causa, o que aconteceria ao Estado se o servidor restituísse o salário recebido.

${ }^{34}$ A maioria desses aperfeiçoamentos está positivada nas citadas Leis n. ${ }^{\circ} 9.868$ e n. ${ }^{\circ} 9.882$ de 1999 e revelam forte influência da hodierna doutrina constitucional alemã. 


\section{Na área do Direito Administrativo.}

(i) No regime da Constituição de 1967, inclusive com a EC n.1 de 1969, o seu art. $102, \S 1^{\circ}$, dispunha que os proventos da inatividade seriam revistos sempre que, por motivo de alteração do poder aquisitivo da moeda, se modificarem os vencimentos dos funcionários em atividade, o que assegurava aos aposentados a manutenção de proventos com valores iguais aos vencimentos dos cargos que exerciam na atividade. Estabeleciase uma isonomia de remuneração entre funcionários ativos e inativos. Pois bem, para conceder elevação salarial aos funcionários ativos e não estendê-la aos inativos, instituiuse a prática de não aumentar os vencimentos dos cargos da ativa, simplesmente, mas promover-se a reclassificação dos cargos ou a reestruturação das carreiras funcionais, mudando-lhes a nomenclatura e atribuindo aos novos cargos salários mais elevados. Assim, por exemplo, um cargo de Fiscal de Rendas, IV, que tinha um salário de R $\$$ 5.000,00, era reclassificado com o nome de Agente de Fiscalização, nível 4, ao qual era atribuído um vencimento de $\mathrm{R} \$ 6.000,00$, enquadrando-se neles os ocupantes do cargo de Fiscal de Rendas, IV. E a lei nada dispunha quanto aos servidores aposentados, de modo que aquele que houvesse sido transferido para inatividade naquele cargo de Fiscal de Rendas, IV, ficaria com a mesma remuneração de $\mathrm{R} \$ 5.000,00$, porque teria desaparecido o seu paradigma remuneratório.

A evidente finalidade dessas leis de reclassificações e reestruturações era, simplesmente, negar a isonomia salarial aos aposentados. Argumentava-se em favor da constitucionalidade dessas leis e da exclusão dos aposentados, que, como a Constituição somente se referia à extensão aos inativos de aumentos de vencimentos dos funcionários em atividade, por motivo de alteração do poder aquisitivo da moeda, e não fazia menção a casos de reclassificação ou reestruturação, não seria possível estendê-los aos inativos. Como parece claro, com esse expediente, se conseguia, respeitando-se as palavras, eludir o sentido da norma constitucional, violando-se o seu sentido, com aparência da mais absoluta normalidade, uma vez que se evitava fim imposto pela Constituição. A infração indireta (=fraude) à regra constitucional era manifesta. No entanto, o STF, chamado a decidir sobre essa inconstitucionalidade deu pela constitucionalidade dessas leis, certamente aplicando a regra de julgar, que o próprio Judiciário se impôs como limitação ao judicial control, de que somente se deve decretar a inconstitucionalidade que seja manifesta $^{35}$, não cabendo decretá-la quando sua constatação dependesse de uma interpretação mais complexa da norma jurídica.

A partir desse entendimento do STF, os Estados-membros se tornaram useiros e vezeiros no uso dessa prática fraudulenta e não mais concediam aumento de proventos

\footnotetext{
${ }^{35}$ Em casos claros, como dizia a Suprema Corte dos Estados Unidos da América(cuja doutrina foi paradigma da nossa), conforme Corwin, A Constituição norte-americana e seu significado atual, p.175.
} 
aos servidores aposentados, senão quando havia revisão geral dos vencimentos, o que passou a ocorrer muito raramente ${ }^{36}$.

(ii) No campo das nomeações para o serviço público, a norma da admissão em cargo mediante aprovação em concurso público sempre foi fraudada, e continua sendo.

No sistema da Constituição de 1946, como o seu art. 186 somente previa a admissão mediante concurso para cargos de carreira, em caráter efetivo, nomeavam-se pessoas para tais cargos na condição de interinos até a realização do primeiro concurso, que raramente era realizado. E mais. Como a Constituição se referia, especificamente, a funcionários públicos, entendia-se que estariam fora dessa exigência os servidores das autarquias, de modo que, para seus quadros de pessoal eram admitidos, além de interinos, os denominados servidores extranumerários. Além disto, criou-se a prática de admitiremse servidores regidos pela CLT, os celetistas, também sem concurso.

Quando a Constituição de 1967 ampliou a exigência de concurso para admissão ao serviço público, incluindo na Seção VII do Capítulo VII, destinada a regular os funcionários públicos referência a cargos, funções ou empregos em autarquias, empresas públicas e sociedades de economia mista $\left(\right.$ art. $\left.97, \S 2^{\circ}\right)$, passou-se a entender que a exigência do concurso alcançaria também as nomeações para aquelas entidades. A partir daí começaram a ser criadas as fundações públicas que, gramaticalmente, estariam fora das proibições e poderiam ter servidores em concurso. Essa fraude somente deixou de existir quando o STF, julgado um caso do Estado do Rio de Janeiro, declarou que as fundações criadas pelo poder público se equiparavam às autarquias, de maneira que se lhes aplicava a exigência de concurso público.

A Constituição de 1988 procurou incluir na exigência de concurso toda espécie de admissão ao serviço público, referindo-se à administração direta e indireta, a cargos e empregos, mas ressalvou, corretamente, as nomeações para cargos em comissão art. 37, incisos I e II. Duas fraudes a esses dispositivos são perpetradas ordinariamente: criaram milhares de cargos em comissão (quando deveriam ser cargos efetivos de carreira ou isolados) para nomeação de apaniguados. Pior ainda, adotou-se o critério de terceirização de serviços públicos, o que possibilita a admissão a prestar serviço público pessoas contratadas por empresas particulares. A terceirização constitui fraude a dois dispositivos constitucionais: art. 37, II, e IX.

(iii) Os Deputados e Senadores, segundo o art. 49, VII, serão remunerados por meio de subsídios, fixados em idênticos valores, observadas as normas dos arts. 37, XI, $39, \S 4^{\circ}, 150$, II, e $153, \S 2^{\circ}$, I, da Constituição. O $\S 4^{\circ}$ do art.39, é taxativo ao estabelecer, dentre outras normas, que o detentor de mandato eletivo será remunerado exclusivamente

${ }^{36}$ Esse procedimento fraudatório ficou tão usual e incômodo que a Constituinte de 1988, em seu texto original, previa a extensão de reestruturações e reclassificações aos aposentados, o que foi reformado pelas EC 19 e 20 - que são formalmente inconstitucionais, como mostraremos adiante. 
por subsídio fixado em parcela única, vedado o acréscimo de qualquer gratificação, adicional, abono, prêmio, verba de representação ou outra espécie remuneratória, obedecido, em qualquer caso, o disposto no art.37, X e XI. $\mathrm{O}$ art.37, dispõe que os subsídios somente poderão ser fixados por lei especial, assegurada revisão geral anual, e o inciso XI, estabelece como teto o subsídio mensal, em espécie, dos Ministros do Supremo Tribunal Federal.

Todas essas normas são cogentes e, portanto, não deixam oportunidade a que se disponha de modo contrário a suas disposições. Pois bem, segundo informa o jornal Folha de S. Paulo ${ }^{37}$, a soma dos benefícios em dinheiro concedidos aos Deputados Federais chega a triplicar seus subsídios, que são fixados em $\mathrm{R} \$ 16.512,09$, e os dos Senadores, que têm o mesmo valor, pode alcançar R $\$ 120,000,00$. Um parlamentar brasileiro custa cerca de $\mathrm{R} \$ 10,2$ milhões ao ano.

Evidentemente, esses benefícios são pagos atendendo a resoluções da Câmara e do Senado que, sem sombra de dúvida, implicam manifestas fraudes às normas do $\S$ $4^{\text {o }}$ do art. 39 e incisos X e XI do art. 37, da Carta Magna.

2. Na área do Direito Tributário. As Constituições brasileiras sempre adotaram princípios na área do Direito Tributário que, por implicarem incômodas limitações ao poder de tributar, são alvos de frequentes fraudes.

(i) A Constituição de 1967, com a Emenda n.1 de 1969, no art. 21, VIII, dispunha que competia à União instituir imposto, dentre outras hipóteses de incidência, sobre produção, importação, circulação, distribuição ou consumo de combustíveis líquidos ou gasosos e de energia elétrica, imposto que incidirá uma só vez sobre qualquer dessas operações, excluída a incidência de qualquer outro tributo sobre elas.

Pois bem, como não poderia institui um tributo qualquer que incidisse sobre o consumo de lubrificantes e combustíveis e a compra de automóveis, pelo Decreto-lei n. ${ }^{0} 2.288$, de 23/11/1986, o Governo instituiu empréstimo compulsório sobre a compra de automóveis e o consumo de lubrificantes e combustíveis, com a finalidade de constituir um Fundo Nacional de Desenvolvimento e para absorção temporária de excesso de poder aquisitivo, cuja devolução seria feita, não pela quantia efetivamente paga pelo contribuinte consumidor de lubrificante e combustível, mas por valor correspondente ao consumo médio por veículo, verificado no ano do recolhimento, segundo cálculo a ser divulgado pela Secretaria da Receita Federal, acrescido de rendimento equivalente ao das Cadernetas de Poupança. Além disto, o empréstimo não seria restituído em dinheiro, mas com quotas do Fundo Nacional de Desenvolvimento que o decreto-lei criava (art.16).

\footnotetext{
${ }^{37}$ Segundo informa o jornal Folha de S. Paulo, edição de 26 de abril de 2010, p.1, A8, e A 11.
} 
É evidente que se tratava de um imposto temporário que tinha por hipóteses de incidência operações comerciais com lubrificantes e combustíveis travestido de empréstimo compulsório para fraudar a proibição constitucional.

(ii) $\mathrm{O}$ mesmo ocorreu com a criação da Contribuição para Financiamento da Seguridade Social - FINSOCIAL (Lei n. ${ }^{0}$ 7.689/88). Não há dúvida das características de um imposto dessa "contribuição". A adoção da denominação se deveu, certamente, ao objetivo de fraudar o art. 157, II, combinado com o art. 154, I, da Constituição, que assegura aos estados-membros uma participação de $20 \%$ da receita de impostos novos que a União vier a instituir, diferentes daqueles que estão expressamente previstos no art. 153, I a VII. No julgamento pelo Tribunal Regional Federal da 4 ${ }^{\text {a }}$. Região do AMS 976-AL, Salgema Mineração Ltda. e outra X Fazenda Nacional, o Relator, Juiz Hugo Machado, preclaro tributarista, proclamou a inconstitucionalidade da lei que criara esse imposto com a denominação de contribuição social, ao argumento de que o expediente teria a finalidade de burlar vedações constitucionais. Não usou a expressão fraude à Constituição, mas o reconhecimento da burla leva à mesma conclusão.

3. Na área do Direito Constitucional (processo legislativo). Conforme mencionamos antes, as normas jurídicas sobre forma, em geral, não são passíveis de fraude. No entanto, seu uso é comum para efetivar violação indireta de lei. No plano do Direito Constitucional, há vários casos em que se utiliza a forma precisamente para fraudar a Constituição. Vejamos algumas espécies.

(i) Voto de liderança. 0 Congresso Nacional, para compensar a lerdeza e ineficiência de seu desempenho na missão de legislar ${ }^{38}$, adotou norma regimental que permite a aprovação de leis pelo voto de liderança dos partidos políticos. Não são os parlamentares que votam pessoalmente, mas cada líder representa o número de votos correspondente ao de parlamentares que integram a sua bancada. É compreensível a medida, se considerarmos que obter quorum num Congresso de ausentes é verdadeiramente difícil.

0 art. 47 da Constituição, entretanto, dispõe textualmente, que as deliberações de cada Casa do Congresso e de suas Comissões serão tomadas por maioria dos votos, presentes a maioria absoluta de seus membros. Diante disso, não há como negar que o voto de liderança constitui uma burla à norma do art. 47, uma vez que se reconhece realidade a um quorum e uma maioria fictícios, o que é incompatível com a Constituição. A nosso ver, embora se trate de uma medida que estaria incluída no conceito de decisão interna corporis (ato que, por essa natureza, segundo espúria interpretação do Congresso, estaria excluído do judicial control), a norma regimental viola indiretamente a Constituição

${ }^{38}$ Segundo o jornal Folha de S. Paulo, edição de 26 de abril de 2010, cit., a produção legislativa do Congresso Nacional chega a ser risível. No ano de 2008, apenas 32 projetos de lei foram aprovados sendo que, destes, 17 se referiam a homenagens, como dar nomes a rodovias, criar feridos, e outras inutilidades que tais. 
e, portanto, as matérias assim aprovadas são nulas de pleno direito em razão de inconstitucionalidade formal.

(ii) Emendas constitucionais com conteúdo de reformas. Não é diferente o que se constata em relação às emendas constitucionais. Ivo Dantas ${ }^{39}$, antes citado, aponta fraude à Constituição na atuação do constituinte derivado nacional que, autorizado pela Constituição de 1988, a promover, após cinco anos de sua promulgação, uma única revisão constitucional, com fim específico e exclusivo (ADCT, arts. $2^{\circ}$ e $3^{\circ}$ ), vem promulgando verdadeiras reformas constitucionais, por seu conteúdo e sua extensão, rotulando-as de emendas, espécie que não encontra limitações, exceto nas denominadas cláusulas pétreas.

Ainda em relação ao constituinte derivado, outra espécie de infração indireta à Constituição tem sido perpetrada. Consoante dispõe seu art. 60, somente se considera aprovado o projeto de emenda constitucional que obtiver voto favorável de três quintos dos Deputados e Senadores, em dois turnos de votação em cada uma das casas do Congresso. Daí resulta evidente que o mesmo texto de proposta de emenda constitucional votado e aprovado em primeiro turno pelo voto de três quintos dos membros da Casa do Congresso Nacional em que se iniciar o processo legislativo, seja também aprovado, por igual quorum e sem alteração substancial de seu conteúdo, em segundo turno de votação na mesma Casa. Remetido à outra Casa do Congresso, deve ser votado e aprovado integralmente em dois turnos. Por consequência incontornável, se em qualquer das votações subsequentes à primeira houver modificação substancial do texto, ter-se-á a proposta como rejeitada.

Pois bem, não é isso o que se tem visto. Emenda Constitucional n. ${ }^{o} 19$ à Constituição de 1988, a denominada Emenda da Reforma Administrativa, por exemplo, foi considerada aprovada e promulgada pelo Presidente do Senado Federal, quando deveria ter sido considerada rejeitada, porque,

a) o texto da PEC apresentado pela Presidência da República ao Congresso não foi aprovado como proposto, em primeiro turno de votação pela Câmara dos Deputados, que alterou seu conteúdo, substancialmente;

b) no segundo turno de votação o texto aprovado na primeira votação foi novamente alterado na própria Câmara dos Deputados;

c) no Senado o texto já aprovado irregularmente pela Câmara sofreu novas alterações, também substanciais, do primeiro para o segundo turno de votação;

d) retornou à Câmara que reapreciou a matéria ${ }^{40}$.

${ }^{39} \mathrm{O}$ valor da Constituição: do controle de constitucionalidade como garantia da supralegalidade constitucional.

${ }^{40}$ De uma análise comparativa entre os textos aprovados nas diversas votações se constata que:

I) na segunda votação pela Câmara o texto aprovado em primeira votação sofreu as seguintes alterações substanciais, de conteúdo: 
A Câmara e o Senado decidiram adotar procedimento legislativo que não se coaduna com o sistema constitucional, aplicando-lhe, indevidamente, a regra do parágrafo único do art.65, que é próprio e exclusivo dos projetos de leis. É evidente que o art. 60 da Carta Magna foi indiretamente violado com aparência de licitude (=fraudado).

(iii) A aprovação do atual Código Civil. Circunstância semelhante ocorreu com a aprovação pela Câmara do Projeto do Código Civil de 2002. O projeto original de iniciativa do Executivo, proposto em 1975, somente foi aprovado pela Câmara dos Deputados em 1986, antes, portanto, da Carta de 1988, que revolucionou em muitos pontos o Direito Civil, em especial a área de Direito de Família. O Senado Federal deixou o projeto dormitando em seus escaninhos, até que o ilustre Senador baiano Josaphá Marinho resolveu desarquivá-lo e aprová-lo antes de concluído seu mandato, tendo feito ajustes que julgava necessários para atender às regas e aos princípios da nova Constituição. No entanto, as correções não foram adequadas, nem pertinentes, de modo que o projeto foi aprovado com inúmeras inconstitucionalidades. Em parecer que elaboramos, em conjunto com o Prof. Assis Gonçalves, da Universidade Federal do Paraná, na condição de Conselheiros Federais da OAB, a pedido do então Presidente do Conselho Federal,

I.a) no art. $3^{\circ}$, que altera o art. 37 da CF, foram excluídas as menções aos incisos IX, XII e XXI e excluídos os seus textos, que se referiam, o inciso IX, ao contrato de emprego público, o inciso XII, ao chamado subteto de remuneração,e o inciso XXI, à licitação pública para contratação de obras, serviços, compras e alienações da administração pública; igualmente, foi excluído o $\S 3^{\circ}$ desse mesmo art. 37, que se referia a audiência de usuários na formulação de políticas públicas.

I.b) no art. $5^{\circ}$, que se altera o art. 39 da CF, foram excluídos: (a) os incisos I a III e respectivas alíneas, que vedavam, expressamente, a concessão de certas vantagens funcionais; (b) o $\S 5^{\circ}$, proibindo incorporação de certas vantagens funcionais aos vencimentos; (c) o $§ 10^{\circ}$ sobre requisição de funcionário público e seu pagamento;

I.c) foi excluído o art. $6^{\circ}$, que dava nova redação ao art.40, II, da $\mathrm{CF}$, relativamente à aposentadoria compulsória;

I.d) no art. $7^{\circ}$, que modifica a redação do art.41 da CF, no caput, o prazo de cinco anos para aquisição de estabilidade foi reduzido a três anos e no $2^{\circ}$ incluiu-se a expressão se estável após as expressões..."eventual ocupante da vaga";

I.e) no art. $8^{\circ}$, o inciso XV do art. 48 teve sua redação substancialmente modificada;

I.f) no art. 11, foram excluídos: (a) da redação do art. 52 da CF, os itens VI a IX, sobre fiscalização de dívidas das entidades intra-estatais rígidas; (b) e o $§ 2^{\circ}$;

I.g) excluído o art.16;

I.h) no art. 20, que altera o art. 132 da CF, reduziu-se para três anos o prazo de cinco anos para aquisição de estabilidade;

I. i) foram excluídos os arts. 30, 32, 33 e 39;

I. j) no art. 25, alterada, substancialmente, a redação do inciso II, do $\S 3^{\circ}$ do art. 169 da CF

II. Do texto da redação final do Senado, ainda foram alterados em relação ao aprovado em primeiro turno no Senado,: (a) o art. 13 (14 do primeiro turno da Câmara) foi excluído; (b) no art. 14 ( 15 da Câmara), o inciso VI; (c) no art. 22, ( 25 da Câmara) o inciso II do $\S 3^{\circ}$ do art. 169 da CF, alterada substancialmente a redação.

É verdade que, embora tenha havido muitas alterações substanciais, boa parte dos dispositivos ou não sofreram alteração e quando sofreram, essas não foram de fundo, mas meramente redacionais. Tal circunstância, porém, não permite entender que estariam aprovados esses dispositivos não modificados e rejeitados os modificados, uma vez que a proposta de emenda à Constituição há de ser entendida como una e unitária, donde não se poder separá-la em partes, mas considerá-la, sempre, como um todo indivisível. 
Reginaldo Oscar de Castro, que já atendia solicitação da Câmara dos Deputados, considerando as inúmeras inconstitucionalidades que constatamos e indicamos no Livro IV da Parte Especial (Direito de Família) e o fato de que, segundo o processo legislativo constitucional, o projeto alterado pelo Senado, como Casa revisora, deveria retornar à Câmara para ou ratificar o texto por ela aprovado inicialmente e rejeitar as emendas do Senado, ou acatar o proposto pela Casa revisora, sem poder modificá-lo, opinamos no sentido de que o projeto não tinha condições de ser aprovado e sancionado, uma vez que o texto aprovado pela Câmara era imprestável, pois votado antes da Constituição, bem assim o do Senado também contaminado por gritantes inconstitucionalidades. Para contornar as normas constitucionais do processo legislativo, a Câmara fez baixar a Resolução n. ${ }^{\circ} 1$ de 2000, estabelecendo que um projeto de código, em tramitação por mais de 20 anos no Congresso, durante os quais haja sido promulgada uma Constituição, poderia ter o texto aprovado pelo Senado revisto pela Câmara para ajustá-lo à nova Carta. E assim foi feito.

Somente que essa resolução implicou uma infração indireta às normas do processo legislativo para as leis ordinárias, o que faz com que seja inconstitucional e, por consequência, inquine do mesmo vício o Código Civil.

(iv) Reapresentação na mesma sessão legislativa de projeto de lei rejeitado. Ainda há mais. O processo legislativo prescreve que o projeto de lei rejeitado não poderá ser reapresentado na mesma sessão legislativa, senão por proposta da maioria absoluta dos membros de qualquer das Casas do Congresso (art.67). Se analisarmos, detidamente, as características da espécie legislativa medida provisória chegaremos à evidência de que tem natureza semelhante a de um projeto de lei de iniciativa do Presidente da República, com a diferença de que recebe força de execução imediata, antes da apreciação pelo Legislativo. No entanto, igualmente aos projetos de lei, necessitam de aprovação do Congresso para que se tornem definitivas. Por esse motivo, uma medida provisória rejeitada ou não aprovada pelo Congresso não poderá ser reeditada e reapresentada à deliberação por iniciativa do Presidente da República. A prática legislativa, porém, admitia que medida provisória não aprovada pelo Congresso fosse reeditada $n$ vezes, com o mesmo conteúdo, apenas com ligeiras modificações de redação.

Essa maneira de agir, é manifesto, infringe indiretamente a norma constitucional, embora aparente respeitar a sua literalidade.

Como podemos concluir, todos esses procedimentos implicam infração indireta dos fins das normas da Constituição, apesar da aparência de licitude. A fraude à Constituição é evidente, não é algo fantasioso, mas real.

4. No direito estrangeiro. Não apenas no Brasil, mas também no estrangeiro a prática existe. A literatura jurídica sobre fraude à Constituição registra ao menos duas situações em que, em países estrangeiros, ocorreram inconstitucionalidades dessa espécie, 
com certa repercussão e discussões perante os tribunais e a doutrina, conforme já mencionamos na justificação do tema.

Na Itália, em 1950, o Governo decidiu executar projeto de reforma agrária e fundiária rural na região do planalto de Sila. A efetivação do projeto enfrentava, no entanto, sérias resistências por parte dos proprietários das terras que precisavam ser desapropriadas, os quais estavam dispostos a discutir na justiça ordinária os atos administrativos da desapropriação. Evidentemente, as ações de desapropriação se eternizariam, o que, se não inviabilizaria, certamente protelaria por muito tempo a execução do projeto.

Para evitar os inconvenientes das ações que tramitariam em juízo ordinário, o Governo obteve a aprovação da Lei de 12 de maio de 1950, n. ${ }^{\circ} 230$, denominada Lei Silana, que, em seu art. $5^{\circ}$, concedeu ao Poder Executivo poderes para praticar os atos de desapropriação por meio de decretos legislativos delegados. A atribuição de natureza legislativa aos atos administrativos destinados a efetivar as desapropriações, acarretou, como consequência prática, a exclusão dos atos expropriatórios do controle judicial pela judicatura comum, incompetente para decidir sobre a constitucionalidade de atos legislativos. Esse expediente caracterizava uma fraude à Constituição italiana, uma vez que não seria possível delegar ao Executivo poderes para praticar típicos atos de administração sob a forma de decretos legislativos delegados. Naquela ocasião travaramse importantes debates na doutrina ${ }^{41}$ e sobre ela manifestou-se a jurisprudência ${ }^{42}$. No entanto, as discussões deram mais relevo ao problema da possibilidade constitucional da delegação legislativa, salvo alguns poucos espíritos mais atilados, como Carnelluti, que viram na lei verdadeira fraude à Constituição.

${ }^{41}$ Vide, sobre o assunto, Giovanni Giacobbe, La frode alla legge, p.85, s., em que são mencionados os seguintes trabalhos: Montesano, Legge incostituzionale, processo e responsabilità (a proposito dell'art. 5 della Legge Silana), in Foro italiano, 1952,IV, 144; Balladori Pallieri, Apunti sulla divisione dei potere nella vigente costituzione italiana, in Rev Trimestrale di diritto pubblico, 1952, p. 811; Mortati, Sui limiti della delegazione legislativa (a proposito della legge di delega per la riforma fondiaria), in Jus, 1952, 206; Guarino, Profili costituzionali, ammistrativi e processuali delle legge per l'altopiano Silano e sulla riforma agraria e fondiaria, in Forto italiano, 1952,IV, 73; Virga, I vizi materiali della legge, in Annali Catania, 1950-51, 25 e ss; Tesauro, La Corte Costituzionale, in Rassegna di diritto pubblico, 1950, I,226, ss; Barile, Profili processuali della legittimità costituzionale, in Giurisprudenza italiana, 1950,IV,103; Carnelutti, Exccesso di potere legislativo, in Revista di diritto processuale, 1947,ii, 193; Pierandrei, Corte Costituzionale, in Enciclopedia del diritto, Milão, 1964, X, 906; Roherssen, L'articolo 113 della Constituzione, le delegazione di potere legislativo e l'attribuizione di forma di legge agli atti amministrativi, in Revista ammistrativa, 1951, 525; Amorth, La costituzionalità della delegazione legislativa per la riforma fundiaria e la impugnazione dei decreti espropiativi davati al Consiglio di Stato, in Giurisprudenza italiana, 1952, IV, 73;Liebman, Il Giudice, la costituzione e la legge Silana, in Ver. di diritto processuale, 1952; Allorio, Una questione di legittimità costituzionale, in Rev. Diritto processuale,,1, 24; Scarpello, Una singolare disposizione della legge 12 maggio 1950, n. 230, in Foro italiano, 1950,IV,164.

${ }^{42}$ Consiglio di Stato de 20 março de 1952, in Foro Italiano, no 6, 1952,III, 83, e n. 7, p. 138. Corte de Cassazione, sentença de 15 janeiro de 1953, n. 108, in Giustizia civile, 1953, I, 74. Corte Costituzionale, sentença de 25 de maio 1957 n. 60, in Giurisprudenza constituzionale, 1957, 684. 
Na Espanha, em obra intitulada Fraude contra Derecho, José Lois Estévez analisa o comportamento dos partidos políticos de esquerda e antifranquistas que, subrepticiamente, se uniriam aos franquistas para negar alguns direitos fundamentais, como, por exemplo, o de votar livremente, e acusa os partidos políticos espanhóis de se mancomunarem para fraudar princípios constitucionais.

\section{CONCLUSÕES}

Não nos parece possível negar que a Constituição pode ser infringida de modo indireto por lei, ato normativo e atos de administração e que tal infringência conduz, necessariamente, à inconstitucionalidade com todos os seus consectários. A sanção a aplicar deve ser a mesma que se aplicaria à inconstitucionalidade por infração direta, porque, em essência, não há diferenças entre elas.

É possível haver certas reservas em se admitir competência ao Judiciário para decretar inconstitucionalidade de leis e atos normativos por fraude à Constituição, por duas razões principais: $(a)$ a expressão fraude pareceria forte demais para qualificar atos dos poderes do Estado e não se coadunaria com o princípio da presunção de legitimidade e validade atribuída a esses atos; (b) a inconstitucionalidade por infração indireta exigiria indagações mais complexas e aprofundadas para identificá-la, o que conflita com a regra de julgar de que a inconstitucionalidade deve ser manifesta, clara, evidente.

A resposta a tais objeções é simples: (a) fraude à Constituição é expressão, efetivamente, inadequada não apenas quando se trata de lei, como também em relação a quaisquer outros atos jurídicos, em razão da indevida conotação de intencionalidade nela presente; o correto é nos referirmos à infração indireta à Constituição, com o que, nos parece, se remove qualquer prevenção contra ela.

(b) atualmente, parece superada essa vetusta concepção que nos vem dos primórdios do judicial control. A doutrina do STF, elaborada a partir da Constituição de 1988, firmou-se no sentido de que também há inconstitucionalidade quando ocorre infringência a princípio constitucional, bem assim quando existe omissão do poder político em dar efetividade a um princípio fundamental, o que implica dizer que pode não ser manifesta e necessitar de hermenêutica aprofundada para identificá-la.

Finalmente, como anotamos no início deste estudo, apesar de a matéria ser praticamente desconhecida da doutrina e da jurisprudência nacionais, o STJ já se manifestou sobre ela ao proferir decisão no RMS 1.796-5, rel. Min. Humberto Gomes de Barros, DJU, I4 out.1993, p.20501, assim ementada:

"É lícito ao Poder Judiciário reparar ofensas ao preceito contido no art. 37, X, da Constituição Federal. No entanto, para que tal reparação se efetive é necessária a prova cabal de que houve fraude ao mandamento constitucional. Não demonstrada a fraude, denega-se a segurança." 
Essa decisão reconheceu, claramente, a possibilidade de o Judiciário decretar inconstitucionalidade por fraude à Constituição e somente não o fez porque não a encontrou demonstrada. Por isso, constitui, em verdade, um marco relevante, parece-nos o primeiro, em relação a admitir a figura da fraude à Constituição e a possibilidade de seu exame pelo Judiciário. Que seja seguida. Esperemos.

\section{REFERÊNCIAS}

ARRAIZ, Javier Perez, El fraude de ley em el derecho tributário. Valencia: Tirant lo Blanch, 1996. AUDIT, Bernard, La fraude a la loi. Paris: Dalloz, 1974.

BLEDEL, Rodolfo, Introducción al estudio del derecho publico anglosajón. Buenos Aires: Depalma, 1947.

BOBBIO, Norberto. Teoria della norma giuridica. Torino: Giappichelli, 1958.

BOUTMY, Émile, Le développement de la consituitionet de la societé politique em Anglaterre, 8. ed. Paris: Librairie Armand, 1930.

CAMPOS, FRANCISCO, Direito Constitucional. Rio de Janeiro/São Paulo: Livraria Freitas Bastos, 1956.

CORNUT, Étienne, Théorie critique de la fraude a la loi: étude de droit international privé de la famile. Paris, Defrénois, 2006.

CORWIN, Edward S., A Constituição norte-americana e seu significado atual. Trad.Leda Boechat Redrigues, Rio de Janeiro: Zahar,s/d.

DANTAS, Ivo, O valor da Constituição:do controle de constitucionalidade como garantia da supralegalidade constitucional. 2. ed. Rio de Janeiro/São Paulo, Renovar, 2001.

DUGUIT, Léon, Traité de droit constitucionnel. 3. ed. Paris, E.de Boccard, 1938

ENNECCERUS, Ludwig; KIPP, Theodor; WOLFF, Martin, Tratado de derecho civil.Trad. Blas Pérez Gonzáles e José Alguer, 2. ed., Barcelona: Bosch, 1953.

ESTÉVEZ, JOSÉ LOIS, Fraude contra Derecho. Madri: Civitas, 2001.

GIACOBBE, Giovanni, La frode alla legge. Milão: Dott.A Giuffrè, 1968.

GIOVANNI, Biaggio, La nulità nella lógica del diritto. Napoles: Morano, 1964.

KELSEN, Hans. Teoria pura do direito. Trad. João Baptista Machado.2. Ed. Coimbra,: Arménio Amado Ed., 1962.

LIÑARES QUITANA, Segundo V., Tratado de la ciência del derecho constitucional argentino y comparado. Buenos Aires: Alfa, 1953.

MELLO, Marcos Bernardes de, Teoria da fato jurídico:plano da existência. 15. ed., São Paulo: Saraiva, 2008.

MELLO, Marcos Bernardes de, Teoria da fato jurídico:plano da validade. 8. ed., São Paulo: Saraiva, 2008.

MELLO, Marcos Bernardes de, Teoria da fato jurídico:plano da eficácia. 5. ed., São Paulo: Saraiva, 2008. 
MORELLO, Umberto, Frode alla legge. Milão: Dott.A Giuffrè, 1969

PINTO FERREIRA, Luis, Princípios de Direito Constitucional Moderno. I, 58, São Paulo: Saraiva, 1983.

PONTES DE MIRANDA, Francisco Cavalcante, Tratado de direito privado. 3. ed., Rio de Janeiro: Borsoi, 1972.

PONTES DE MIRANDA, Francisco Cavalcante, Comentários à Constituição de 1967, com a Emenda n.1/69. 2. ed., São Paulo: Revista dos Tribunais, 1970.

TUHR, Andreas Von, Teoria general del derecho privado alemán. Trad. Tito Rava, Buenos Aires: Depalma, 1946.

Recebido: agosto 2010 Aprovado: abril 2011 